\title{
Hizmet Sektöründe Kadın Girişimciler: Çorum Araştırması
}

\author{
Dr. Öğretim Üyesi Hülya Çağıran Kendirli ${ }^{1 *}$ \\ Şükran Ayça Şenöz ${ }^{2}$
}

Geliș tarihi: 02.01.2019

Kabul tarihi: 15.02.2019

\section{Atıf bilgisi:}

Uluslararasi Bilimsel

Araştırmalar Dergisi (IBAD)

Cilt: $4 \quad$ Sayı: 1

Sayfa: 93-118 Yll: 2019

Dönem: Kış

This article was checked by iThenticate. Similarity Index 15\%

\section{${ }^{1}$ Hitit Üniversitesi, Türkiye, hulyacagirankendirli@hitit.edu.tr, ORCID ID 0000-0002-1526-0337 \\ ${ }^{2}$ Hitit Üniversitesi, Türkiye, aycasenoz@hitit.edu.tr, ORCID ID 0000-0001-7792-4170}

* Sorumlu yazar

\section{ÖZ}

Günümüzde sosyal ve endüstriyel değişimler kadının iş hayatına girmesinde önemli bir etkendir. Teknolojideki yeniliklerin günden güne artmas1 sebebiyle bilgiye erişmenin kolaylığı eğitimli kadın sayısında artışa neden olmuştur. Bu anlamda girişimcilik kadınlar için daha cazip iş alanlarının açılmasını sağlamaktadır.

Bu çalışmanın amacı, Çorum'da faaliyet gösteren kadın girişimcilerin hem cinsiyete dayalı girișimci özelliklerinin ve niteliklerinin belirlenmesi, hem de hizmet üretimi bağlamında değerlendirilmesidir. Bu çerçevede, kadın girişimcileri üretim sektörüne yönlendirmek adına bu çalışmada önerilerde bulunulmuştur.

Anahtar Kavramlar: Girişim, Girişimcilik, Kadın Girişimciliăi, Hizmet Üretimi 


\title{
Women Entrepreneurs in The Service Sector: Corum Research
}

\author{
Asst. Prof. Dr. Hulya Cagiran Kendirli ${ }^{1^{*}}$ \\ Şükran Ayça Şenöz ${ }^{2}$
}

First received: 02.01.2019

Accepted: 15.02 .2019

\section{Citation:}

Journal of the International

Scientific Research (IBAD)

Volume: 4 Issue: 1

Pages: 93-118 Year: 2019

Session: Winter

\begin{abstract}
Today, social and industrial changes are important factors for women to enter the business world. Since the innovations in technology have increased day by day, the ease of access to information has led to an increase in the number of educated women. In this sense, entrepreneurship provides more attractive work areas for women.

The aim of this study is to determine both the gender-based entrepreneurial characteristics and qualifications of women entrepreneurs in Çorum and to evaluate them in the context of service production. In this framework, suggestions were made in this study in order to direct women entrepreneurs to the production sector.
\end{abstract}

Keywords: Initiative, Entrepreneurship, Women's Entrepreneurship, Service Production

\author{
${ }^{1}$ Hitit University, Turkey, \\ hulyacagirankendirli@hitit.edu.tr, \\ ORCID ID 0000-0002-1526-0337 \\ ${ }^{2}$ Hitit University, Turkey, \\ aycasenoz@hitit.edu.tr, \\ ORCID ID 0000-0001-7792-4170
}

* Corresponding Author

Similarity Index 15\% 


\section{GíRIŞ}

Girişimcinin, üretim elemanlarını bir araya toplayarak iktisadi ürün veya hizmeti insan ihtiyaçlarını karşılayacak şekilde piyasaya sunacak ortam bulması ya da imkan oluşturması ekonominin geliştirilmesine büyük bir katkı sağlamaktadır. Teşebbüste bulunan bireyler, pazarları takip edip insanların ihtiyaç ve isteklerini analiz etmektedir. Bununla birlikte girişimciler, mevcut talebin dışında yeni talepler de oluşturabilen, tüketici ihtiyaç ve isteklerindeki farklılaşmayı zamanında analiz eden, üretim kaynaklarını bir araya getirerek üretim yapabilen ve rekabetten kaçınmayan bireylerdir. Girişimciler rekabet etmekten kaçınmak yerine, rekabet unsurunu varlığının temel gereklerinden biri olarak kabul etmektedirler.

$\mathrm{Bu}$ doğrultuda girişimcileri risk almaktan ve sorumluluk almaktan korkmayan, atik ve üretken bireyler olarak nitelendirmek yanlış olmayacaktır. Teşebbüste bulunan bireyler için ekonomik fayda sağlama, bahsedilen temel çabaların neticesinde kendiliğinden elde edilmektedir. Tabii ki bu ödül, şartları iyi değerlendiren ve doğru zamanda, doğru yerde hayallerini hayata geçiren girişimciler için mümkündür. Girişimcilik, temelde bireyin içindeki güdü ile başlamaktadır.

Girişimcilik, bireyin, bağımsız ya da herhangi bir kuruluş içerisinde, bir fırsatı belirleyip yeni bir değer meydana getirerek ekonomik fayda sağlamak adına belirlenen fırsatın peşini bırakmadan üzerine gitme güdüsünü ve bu güdünün düzeyini ifade etmektedir. Teşebbüste bulunan birey, mevcut bir piyasaya dâhil olmak ve rakiplerle mücadele etmek, dâhil olunan piyasayı değişime uğratmak ve hatta yeni bir piyasa oluşturmak adına yaratıcı düşünceden veya inovasyondan (Erdemir ve Palaz Erdemir, 2016, s. 59-78) faydalanmaktadır.

Girişimciliğin sadece gerçekleştiren bireye değil, ülke ekonomisine ve topluma da birçok faydas1 bulunmaktadır. Bunlar arasında, yeni istihdam ya da istihdam alanları oluşturulması, işsizlik oranının düşürülmesi, iktisadi kalkınmaya destek olunması, yeni iş kollarının geliştirilmesi, yaşam kalitesinin yükseltilmesi, refahın toplumsal tabana yayılmasına destek olunması gibi etkilerin yanında dengesiz bölgesel gelişmişliğin ortadan kaldırılması, geliştirilen yeni buluşların insana faydalı ürün veya hizmetlere dönüştürülmesi, toplumun değişim ve gelişim süreçlerinde destek olunması gibi ekonomik ve sosyal etkileri de bulunmaktadır. Kadınların girişimci olmalarının sebepleri incelendiğinde, çoğunlukla iktisadi koşulların zorlaşmasından kaynaklanan maddi ihtiyaçların karşılanması ve çalışarak gelir elde etme imkanlarının olmaması (işsizlik) gibi nedenler ortaya çıkmaktadır. Bu arada cinsiyetle ilgili fiziki yapılarına bağlı olarak iş bulma imkânlarının sınırlı olmasının da etkisi söz konusudur.

$\mathrm{Bu}$ çerçeve içerisinde bu çalışmanın amacı; girişimciliğin öneminin ve özelliklerinin açıklanması, girişimciliğin ekonomik ve sosyal gelişmeye etkisinin incelenmesi, hizmet üretiminde kadın ile erkek girişimcilerin karşılaştırılmasının yapılması ile birlikte hizmet üretiminde kadın girişimciliğinin yerinin Çorum ili esas alınarak bir değerlendirilmesidir. Çalışma literatür taramasının yanında Çorum ilinde gerçekleştirilen anket çalışması ile de desteklenmiştir.

\section{ÜRETIM, HIZMET VE GIRIŞiMCILIĞĞiN KAVRAMSAL ÇERÇEVESİ}

\section{Üretim ve Hizmet Kavramının Tanımı ve Önemi}

İşletmenin üç temel fonksiyonundan biri olan üretim; ekonomistlere göre her türlü fayda sağlamak veya iktisadi mal/hizmet meydana getirmek, mühendislere göre fiziki bir varllğğn üzerinde onun değerini arttıracak değişim uygulamak (hammaddeyi kullanılabilir ürüne dönüştürmek gibi), işletmecilere göre ise fayda üretmek (hammaddeyi fiziksel veya kimyasal yollar kullanarak değiştirmek) ve böylece tüketicilere faydalı mal veya hizmet sunmak anlamına gelmektedir. Bu farklı ifadeler bağlamında üretimin temel amacı ise, bir mamul veya bir hizmet oluşturmak ya da üretmektir. Üretilen mal bir başka işletmenin hammadde kaynağı olabileceği gibi nihai tüketim ürünü de olabilmektedir. Bir başka açıdan ele alacak olursak hizmetler de insan ihtiyaçlarını karşılamaya yönelik bir faaliyet olduğu ve ülke ekonomisine katkıda bulunduğu için üretim faaliyeti olarak sayılmaktadır (Kobu, 2017, s. 4).

Üretim sadece bir ürünün meydana gelmesi adına yapılan faaliyetler ile sınırlı değildir. Bir ürünün oluşumunda ürüne değer katan veya değerini arttıran faaliyetler de üretim olarak tanımlanmaktadır (Yamak, 1999, s. 15). Üretim faaliyetlerinde yeni ürün meydana getirmek önemli olduğu kadar, asıl olan 
üretim kaynaklarının verimli kullanılmasıdır. $\mathrm{Bu}$ da etkin üretim yönetiminin sağlanması ile mümkündür. Dolayısıyla üretim bir değer oluşturma ve ortaya koyma sürecidir (Russell \& Taylor, 1995, s. 3).

Üretime dayalı süreçlerde ölçülebilen ve depolanabilen somut ürünler elde etmek mümkün iken, hizmet üretimi esnasında tüketiciye doğrudan değer sağlayan soyut çıktılar elde etmek mümkündür. Bu bir iş veya bir çaba gibi somut olmayan bir değer olabilir. Danışmanlık, bakım, taşımacılık, sigortacılık veya eğitim hizmetleri, hizmet sektörünün çıktılarına örnek teşkil etmektedir. Hizmet sektörünün daimi olabilmesi için etkin bir imalat sektörü gerekmektedir. Mesela finansal hizmetler, sigorta, reklam ve taşımacılık gibi hizmetlerin varlığını sürdürebilmesi, sağlıklı bir imalat sektörünün varlı̆̆ ile mümkün olmaktadır (Üreten, 2006, s. 23-24).

Genel anlamda imalat ve hizmet sektörleri arasında farkl11ıklar bulunmakla birlikte, bu farklılıların niteliği üretim yönetimi tektiklerinin hizmet üretimi gerçekleştiren işletmelerde kullanımını engelleyen özellikte değildir (Üreten, 2002, s. 23). Üretim ve hizmetler yönetiminde amaç, üretiminde bulunulan ürün ve hizmetlerin kalite ve fiyat gibi nitelikleri ile üretici ve tüketicilerin tatmin olmasını ve talebin sürekliliğini sağlamaktır (Yüksel, 2009, s. 1).

Üretimin temelini insani taleplerin karşılanmasında etken olan ekonomik faaliyetler oluşturmaktadır. Müşteri ihtiyaçlarını karşılamak amacıyla mal ve hizmet üretmek ve bunun sonucunda ortaya çıan gelirin arttırılması ülke ekonomisine katkıda bulunmaktadır. Dolayısıyla üretim artışı hedeflenerek uygun yatırım alanlarına yönelmek ve kaynakların verimli kullanımı ekonomik gelişmenin yönünü belirlemektedir (Tekin, 2012, s. 3-5).

\section{Girişimcilik Kavramı}

Ekonomik bir kuram olarak "girişimcilik" terimi ilk defa 1759'da, İrlanda asıllı Fransız iktisatçı Richard Cantillon tarafından ortaya atılmıştır. Cantillon girişimciyi risk alma uzmanı olarak adlandırmıştır (Casson, Yeung, Basu, \& Wadeson, 2006, 3). Girişimcilik kavramının içeriği genişletilerek, girişimciyi bu şekilde risk alma uzmanı olarak tanımlamanın yetersiz olduğu fark edilmiş ve girişimciliğe; organize etme, planlama ve üretim faktörlerini kullanma özelliklerini ekleyerek yeni bir tanım geliştirilmesi 18 . yüzyıl sonlarında mümkün olmuştur. 18. yüzyılda fon tedarik eden sermaye sahibi ile sermaye sahibinin fonlarından kazanç elde etmesini sağlayan girişimci ayrımı yapılmaya başlanmıştır (Arıkan, 2004, s. 4$6)$.

Literatüre bakıldığında girişimcilik kavramı üzerine farklı yazarlar tarafından yapılan pek çok tanımlara rastlanmaktadır. Girişimcilik kavramı Fransızca' da "entrepende", Almanca' da "unternehmen" sözcüklerinden türetilmiştir. Türkçe' de ise, "üstlenmek" anlamına gelmektedir (Arıkan, 2016, s. 45). Girişimcilik, evrensel olarak kabul gören tek bir tanım ve niteleme olmaksızın, pek çok kişi tarafindan çeşitli şekillerde nitelendirilmiştir. Morrison (1998), girişimciliğin pazar firsatlarını kullanmak için benzersiz bir kaynak paketini toparlayıp, değer yaratma sürecini içerdiğini ifade etmektedir.

Girişimcilik, genellikle yeni bir teşebbüs oluşturma anlamında özetlenmiştir (Kurt \& Savrul, 2016, s. 343). Girişimcilik; geleneksel olarak satı̧s veya kiralama için bir ürün, süreç veya hizmet sunan; yeni kurulmuş bir işletme gibi faaliyete geçirme ve yönetme süreci olarak açılanmıştır (Rajavel, 2016, s. 12).

Girişimcilik ekonomik büyümenin başlıca unsurlarından biridir. Girişimci, üretim gereklerini bir araya toplayarak iktisadi ürün veya hizmet üreten ve ürettiği ürün veya hizmeti ekonomiye dönüştürebilecek ortam bulan ya da yaratan kişidir. Ekonominin oluşturulması adına amacıyla ihtiyaç duyulan üretim unsurlarının bir araya getirilmesi, biyolojik ya da mekanik bir işlem olmamakla birlikte insanların gerçekleştirdiği bir faaliyettir (Bozkurt vd., 2012, s. 232).

Girişimcilik; sosyal, fiziki ve ekonomik risklere katlanmak suretiyle kişisel tatmin, bağımsızlık ve maddi ödüller elde edilerek yeni bir değer meydana getirme aracıdır. Bu tanımda da görüleceği üzere girişimci olmanın dört temel özelliği vurgulanmaktadır (Atik, 2002, s. 3-4): Bunlardan ilki, girişimciliğin yaratıcılık ve yenilik sürecini barındırması gerektiğidir. İkincisi, girişimcilik sürecinde gerekli zaman ve çabanın ayrılması gerektiğini vurgular. Girişimcilikte gerekli riskleri üstlenmek, girişimciliğin bir diğer 
yönünü oluşturmaktadır. Sonuncusu ise bağımsızlık, kişisel tatmin ve maddi ödüller gibi girişimciliğe yönlendiren sosyolojik etkenlerdir.

Girişimciliğin bir diğer tanımı; maddi kazanç ve kişisel tatmin elde etme sürecinde katma değere sahip farklı şeyler meydana getirmek amacıyla, gerekli zamanı ayırıp, çaba göstererek siyasi, ekonomik ve psikolojik risklerin alınmasıdır (İlter, 2010, s. 8). En genel anlamıyla girişimcilik firsatlardan yararlanabilme ve yeni firsat oluşturabilme amacıyla üretim girdilerini örgütleme yeteneği ve risk alma özelliklerini kullanarak çıktıya dönüştürmek olarak tanımlanmaktadır (Tosunoğlu, 2003, s. 1). Girişimcilik kavramı literatürde pek çok yazar tarafından farklı boyutlarıyla ele alınmıştır. Bu konu ile ilgili bütün tanımlamaların ortak noktası girişimciliğin ekonomik imkanları yeni değerlere dönüştüren bir firsat olarak nitelendirilmesidir (Yörük ve Ağca, 2006, s. 160).

Bir ekonomide üretimin vazgeçilmez unsurlarından biri de girişimciliktir. Emek, sermaye gibi üretim faktörleri girişimcilik kabiliyeti ile desteklendiğinde kaynakların verimli kullanımı söz konusudur. $\mathrm{Bu}$ özellikleri ile girişimciler günümüzde etkin konumdadırlar (Küçükaltan, 2009, s. 21).

Girişimcilerin en büyük amaçlarından birisi, toplumun ihtiyaç ve beklentilerini doğru analiz edip, onların daha rahat bir hayat sürmelerini sağlamak ve gelir artışına paralel olarak istihdam hacmini orantılı bir şekilde arttırmaktır. Girişimcilerin gerçekleştireceği projelerde önemli olan milli gelir düzeyini arttırmaya yönelik yatırımlardır.En yüksek faydayı sağlamak için; bu bağlantı içerisinde işsizlik problemleri, ücret eşitlikleri, üretim ağırlıklı teşvikler, dış bütçe imkanları ve olabildiğince yerli kaynaklardan faydalanmak gibi verileri gözden kaçırmamak önemlidir. Bir girişimci için para motivasyon sebebi değil motivasyon aracı olmalıdır. Başarı, motivasyonun ana faktörüdür, para ise sonuçta elde edilen ödüldür (Arıkan, 2004, s. 41).

\section{Üretim ve Girişimcilik İlişkisi}

Bir ülkenin ekonomik ve sosyal kalkınma düzeyinin belirlenmesinde girişimciliğin payı büyüktür. Ülkedeki girişimcilik olgusu, girişimciliğin oluşması için gerekli olan altyapı, girişimcilik kültürü ve bu konu üzerine kurulan strateji ve politikalara bağlıdır (Alkan, 2014, s. 17). Girişimciler üretim kaynaklarını farklı şekillerde birleştirerek kullanımı olmayan üretim girdilerini tekrar kullanıma sunar. Dolayısıyla girişimci, iktisadi kaynakların düşük üretkenlik alanlarından verimliliği yüksek alanlara aktarılma sürecinde etken faktördür. $\mathrm{Bu}$ yönüyle girişimci toplumsal refaha katkıda bulunan ve toplumsal fayda sağlayan en önemli bileşendir (Tekin, 2005, s. 9).

Girişimci kendisinin ve bir başkasının meydana getirdiği değerleri ekonomiye kazandırmaktadır. $\mathrm{Bu}$ çerçevede yapılan en ufak bir yenilik ve değişim dahi üretim sürecine olumlu etkide bulunmakta ve verimlilik artışına sebebiyet vermektedir. Yapılan yeniliğin seviyesi arttıkça ekonomiye olan katkısı da doğru orantılı olarak değişmektedir. (TÜSİAD, 2002, s. 18)

\section{Girişimciliği Etkileyen Faktörler}

Girişimcilikle ilgili yapılan çalışmalar dikkate alındığında, incelenmesi gereken hususlardan birisi de girişimciliği etkileyen unsurların neler olduğudur. Girişimcilerin yaşadıkları toplumdan ve çevreden bağımsız düşünmeleri son derece yanlış olur. Yaşadıkları çevreyi etkileyen söz konusu girişimcilik etkenleri kimi zaman kişisel, kimi zaman da çevresel faktörlerden kaynaklanmaktadır. Girişimciliği etkileyen birçok unsur vardır. Bunlar; sosyal çevre, aile, kültür, eğitim ve psikolojik faktörler olabileceği gibi siyasi, idari ve mali içerikli de olabilir. Bu faktörlerin girişimciliğe etkileri özetle ve ayrı ayrı aşağıda ele alınmıştır; (İraz, 2005, s. 176-178)

- Kültür: Kültür, tarihi ve sosyal gelişim sürecinde, bulunduğu coğrafyaya göre var olan değerlerdir. Girişimciliğin ana hususları bazı kültürlerde destek alırken, bazı kültürlerde ise henüz kabul görmemektedir.

- Aile ve Sosyal Çevre: Ailede alınan eğitim düzeyi, görgü seviyesi, görenek ve bunun gibi etkenler çocuğun girişimcilik arzusu ve kabiliyeti üzerinde kararsızlık yaratıcı etki, olumlu veya olumsuz etki birakabilmektedir. 
- Hukuki, Siyasi ve İdari Faktörler: Girişimciliğin daha rahat kök salıp gelişebilmesi için yasalarla, ekonomi politikaları ve bürokratik sistemle özendirilmesi gerekmektedir.

- Mali Çevre: Girişimciliğin uygulanabilmesi için öncelikle uygun bir mali ortamın sağlanması gerekmektedir.

- Eğitim: Girişimcinin aldığı eğitimler, gerek aile içinde gerekse eğitim kurumlarının yönlendirmesi sonucu, yaratıcılı̆̆ının gelişmesine yardımcı olur. Gelişmiş ülkelerin birçoğunda bireylerin firsatları görüp, yeni iş imkanları yaratabilmesi için bireylere ilköğretim ve lise düzeyinden itibaren girişimcilik yönünde eğitimler verilmektedir.

- Psikolojik Faktörler: Girişimcilerin göstermiş olduğu psikolojik davranışlar, girişimciliği doğrudan etkilemektedir.

\section{Cinsiyetin Girişimcilik Üzerine Etkisi}

Cinsiyetlere yüklenen rollerin netice olarak, girişimcilik üzerinde öncelikle önyargı açısından tesir ettiğini söylemek mümkündür. Milyonlarca kadının gayet yaratıcı şekillerde yeni iş alanları yaratması, başarılı bir biçimde iş kadınlığı ve ev kadınlığı yükümlülüklerini yerine getirmesi, her birinin iyi bir iş insanı olduğunun açık bir göstergesidir. Yapılan bu açıklamalar dikkate alınacak olursa, erkek girişimciler vakitlerinin önemli bir kısmını, günlük rutin işleri ile geçirmektedirler. Kadın girişimciler ise daha geniş ve çeşitlilik içeren, ev, eş ve çocuklarına bakmaktadırlar. Bununla birlikte, kadınlar aynı zamanda iş hayatlarını da devam ettirmek zorundadırlar. $\mathrm{Bu}$ durum ise kadın girişimcileri, erkek girişimcilere göre daha başarılı olmaya zorlamaktadır (Cici, 2013, s. 56).

Sosyo-kültürel faktörler ve girişimci güdüler, kültür kalıplarını ve girişimci kişileri ortaya çıkarmaktadır. Çünkü, bu etkenler, kişiye; ileri görüşlülük, risk kontrolü, sorumluluk gibi nitelikler edindirdiğinden, sonuç olarak, aktif çalışmak, işleyen bir iktisadi sistem ve aktif girişimciler ortaya çıkarmaktadır. Aktif girişimciler, yeni imkan ve firsatlardan faydalanarak, kaynak üretimi, toplum hareketliliği, ve canlılık sağlarlar. Hedeflenen bir durum olmamakla birlikte, zaman zaman kültürün engelleyici özelliği neticesinde kişi, doğal olarak iş yapmamaya yani tembelliğe yönelir. Bu sebeple toplum, ekonomik ve sosyal hayat tesirini kaybeder. Bu yönde yapılan çalışmalar özgürlükçü, açı/kesnek ve serbest piyasa şartlarının girişimcilik kapasitesini yükselttiğini ortaya çıkarmaktadır (Aytaç ve İlhan, 2007, s. 18)

Cinsiyet etkeninin meydana getirdiği roller, girişimcilere sektör seçimi için daha belirleyici olmaktadır. Kadın girişimcilerde sektör tercihi hizmet üzerine olurken, erkeklerde ise üretim, inşaat ve teknoloji sektörü olmaktadır. Bu da kadınların erkeklere göre küçük ölçekli işletmelere sahip oldukları anlamına gelmektedir (Hisrich ve Peters, 1998, s. 78-80).

\section{KADIN GIRISSTIMCILİK VE ÜRETIMDEKİ YERİ}

\section{Kadın Girişimciliği Kavramı}

Bu konuda yapılmış bütün bilimsel araştırmalarda kadın girişimci, evinin haricinde yalnız, bir veya birkaç ortakla ya da çalıştırdığı elamanlarıyla beraber kurduğu işletmesi ile ilgili özel ve tüzel kurumlarla iletişim kurabilen, kazancını kendi tasarrufları doğrultusunda özgürce kullanabilen, risk yüklenebilen kimse olarak ortaya çıkmaktadır (Erktürk, 2015, s. 42).

'Kadın girişimciliği' kavramı, genel olarak 'girişimcilik kavramı' ile ilişkilendirilerek tanımlanmıştır. Bazı yazarlar kadın girişimcileri işletme sahibi olarak adlandırırken bazıları ikinci kuşak işletme sahibi olan kadınları da kadın girişimci olarak ele almaktadır. Bazı kaynaklar ise kadın girişimciliğinden küçük girişimler olarak bahsetmektedir (Gökakın, 2000, s. 109).

Dhillon (1993) kadın girişimciliğini, kendi işinin sahibi olan, tek çalışan veya elemanlarıyla beraber çalışan, mal veya hizmet üretip pazara sunan, olası acil durumların üstesinden gelebilen ve yeni durumlara kolaylıkla uyum sağlayabilen kadını, 'girişimci kadın' olarak adlandırılmaktadır (Dhillon, 1993, s. 101). Sinanoğlu-Koç (2005) ise genel olarak kadın girişimciliği, işletme sahibi kişi olarak risk alarak ekonomik, yönetimsel ve toplumsal sorumluluklarla birlikte yeni girişimleri başlatan, işletmenin yönetimini kendi üstlenen kadın olarak tanımlamaktadır (Sinanoğlu Koç, 2005, s. 45). 
Literatürdeki diğer çalışmalara bakıldığında kendi mesleğini ifa eden kadınlar girişimci olarak kabul edilmemektedir (avukat, akademisyen, doktor gibi). Bunun sebebi olarak girişimciliğin, kar ve zarar riskini göze alarak üretim faktörlerini bir araya getirme konumunda olmasıdır (Bedük, 2005, s. 73). Bir diğer tanıma göre kadın girişimci bizzat işinin başında bulunan, sahip olduğu işletmenin idari ve hukuki sorumluluğunu üstlenen ve işyerinde fiili çalışan kadındır. Aynı zamanda işgücü ve sermaye kaynaklarını verimli kullanacak tedbirleri alan, yaratıcı ve rasyonel iş fikirleri üreten, oluşabilecek risklere planlı önlemler alabilen kadındır (Saray, 1993, s. 118).

Bölgesel kalkınmanın hızlanması ve artması için, girişimciyi ve girişimcilik politikalarını desteklemek büyük önem arz etmektedir. Kadın girişimciliğinin gelişimini desteklemek, hem ekonomik kalkınmaya faydası olduğu gibi hem de kadın işsizliğine bir çözüm unsuru olarak önemli bir araç haline gelmektedir. Bu yüzden son yıllarda diğer ülkelerde olduğu gibi Türkiye'de de kadın girişimciliği kavramı büyük önem teşkil etmektedir. Akademik çalışmalara ve piyasadaki girişimci algısına bakıldığında, girişimcinin piyasa açıklarını değerlendirip, hem topluma hem de kendisine fayda sağlayan üretim faktörü olduğu görülmektedir. Politikacılar, iktisadi kalkınmanın gerçekleşmesi için, yeni iş alanları yaratılmasını, girişimciliğin gelişimi ve yaygınlaşmasını destekleyecek çalışmalar yapılmasının konusunun gerekliliğini vurgulamışlardır. Bu bağlamda girişimciliğin istihdam ve iktisadi kalkınma ile bağının olduğu açık ve nettir. Küreselleşmenin tüm ekonomilerde yarattığı işsizlik ve ekonomik durgunluk, girişimcileri strateji belirlemede farklı araçlar bulma yoluna itmiştir. Girişimciliğin teşvik edilmesine yönelik stratejiler siyasetin ve iktisadın başlıca gündemi haline gelmiştir.

Globalleşme dönemiyle birlikte etkin ölçüde yaygınlaşan girişimcilik anlayışı, erkekler kadar kadınları da etkileyerek, onları iş yaşamının değişmez oyuncuları haline gelmesini sağlamıştır. Buna göre de kadının toplumdaki yeri ve öneminde anlamlı değişiklikler meydana gelmiş̧tir (Takay vd., 2014, s. 8).

Günümüzde kadınların çalışma ortamlarında etkinliklerini arttırmaları, hem kendileri hem de toplum açısından önem arz etmektedir. Bilhassa kadının eğitimli, hırslı, yapıcı ve kararlı duruşu, kadını erkeğe tabi olmaktan uzaklaştırarak ekonomik güce ulaştırmakta ve toplumdaki konumunun güçlenmesine imkân vermektedir. Kadının güçlenmesini temin eden en önemli kaynak ise onun girişimci niteliğidir. Girişimcilik icrası ile kadınlar, bir yandan maddi ve manevi avantajlar sağlarken, öte yandan, özgürlük, mali imkânlar, sosyal hizmetler gibi nitelikler ile de cinsiyet ayrımcılığına yönelik ön yargıları pozitif hale getirme firsatı elde etmiş olmaktadırlar (Soysal, 2010, s. 110). Girişimcilik günümüzde yeni ele alınan bir alan olmakla birlikte, sayıları az olsa da tarihte de girişimci kadınlara ve bahsi geçen türden avantajlar sağladıklarına dair örnekler kaynaklarda yer almaktadır (Erdemir, 2010, s. 104-129; Palaz Erdemir, 2018, s. 571-595). Bu örnekler, günümüz insanına kadın girişimciliği konusunda kıymetli bir motivasyon sağlayabilmesi bakımından oldukça önemlidir.

\section{Kadın Girişimciliğinin Önemi}

Günümüzde sosyal ve endüstriyel değişimler kadının iş hayatına girmesinde önemli bir etkendir. Teknolojideki yeniliklerin günden güne artması sebebiyle bilgiye erişmenin kolaylığı eğitimli kadın sayısında artışa neden olmuştur. Bu anlamda girişimcilik kadınlar için daha cazip bir iş alanı hale gelmektedir (Güney, 2006, s. 26).

Üretim sektörlerinin küçülmesi, bunun yanı sıra hizmet sektörünün çalışma alanı bakımından gittikçe büyümesi, istihdam oranının sanayi sektöründen hizmet sektörüne doğru kaymasına neden olmaktadır. $\mathrm{Bu}$ durum, hizmet sektöründe kadın çalışan ve kadın girişimci ihtiyacının artması sonucunu doğurmuştur. Kadın girişimcilerin artma sebepleri şöyle sıralanabilir (Gürol, 2000, s. 242):

- Sosyolojik ve teknolojik değişimler sonucunda kadınların eğitim seviyelerinin artması ve dolayısıyla çalışma hayatına girmeleri,

- Orta veya düşük kadrolarda çalışan kadınların, görev yaptıkları işletmelere işten atılma kaygısı güderek, kendi kendilerinin patronu olmayi talep etmeleri,

- Başarılı kadın girişimcilerin sayısındaki artışın gerçekleşmesi ile model alınabilecek insanların çoğalması, 
- Cam tavan olarak adlandırılan, kadınların işletmelerde belli bir düzeye kadar yükselebileceği fikriyle hareket ederek iş kurma arzusunu gerçekleştirmeleri kadın girişimci sayısının artma nedenleri arasında gösterilebilir.

\section{Kadın Girişimcilerin Özellikleri}

Kadın girişimciler, erkek girişimcilerle birçok ortak özellikler taşımaktadır. Ancak, kadın girişimciler, erkek girişimcilerden farklı olarak, aile hayatlarına paralel hareket etmektedirler. Aile hayatının sorumlulukları daha çok kadınlarca üstlenildiği için ileriye dönük ve planlı hareket etme yönünde yoğunlaşmışlardır. $\mathrm{Bu}$ ve benzeri nedenlerle erkek girişimciliğinden bir ölçüde farklı olan kadın girişimciliğinin özellikleri, bileşenleri açısından şöyle sıralanabilir (Bozkurt vd., 2012, s. 150).

Kadın girişimcinin;

- Merakı her zaman diridir. Merakları dolayısıyla firsat ve tehlikeleri sezinleyebilirler.

- Düşünce yapısı bakımından daima fark oluşturabilirler, kendilerini yenileyebilirler.

- Kendisi için oluşturduğu ve uyduğu daimi kuralları vardır.

- Özgüven sahibi oldukları için, çevresine de güven aşılayabilirler.

- Hayal güçleri yüksektir. Bu sayede ayakları yere sağlam basar. Fikirlerine yön veren tutarlı bir felsefeye sahiplerdir.

- İş yapmak için geliştirdiği yöntemler vardır.

- Olumsuzluklarla yüzleşebilir ama pozitif bakış açısını korur.

- Tek başına karar almak yerine, düşüncesini paylaşarak ortak akıldan faydalanır.

- İşlerini sözel olarak yapmaz yazılı bilgi ve kayıt sistemi geliştirirler.

- En iyi bildiği iş üzerinde odaklanır, dikkatini ve gücünü bu alanda yoğunlaştırır.

\section{Kadınları Girişimci Olmaya Yönlendiren Faktörler}

Kadınların iş kurma nedenlerini "itme ve çekme" faktörleri çerçevesinde değerlendirecek olursak; kadınların yaşadığı ekonomik sorunları, kadınlara uygun olmayan iş programları ve kadınların cinsiyet ayrımcılığına maruz kalmaları 'iten faktörler' arasında değerlendirilebilir. Diğer ülkelerde yapılan çalışmalara bakıldığında, çalışan kadınların sayısındaki artışı işsizlik sorunlarıyla bağdaştıran araştırmaların olduğu görülmektedir. Kadınlar yaşadıkları ekonomik sorunlar nedeniyle girişimciliğe yönelmişlerdir. Esnek istihdam politikaları ve işçi çıkarımlarında özellikle kadınların tercih ediliyor olması kadınları küçük ölçekli işyeri sahibi olmaya yöneltmiştir. 'Ç̧eken faktörler' ise kadınların kendi hayatlarında bağımsız olma isteği, kendi işinin patronu olma arzusu, kendini gerçekleştirme ve aile ve iş ortamı arasındaki dengeyi kurma isteği şeklinde sıralanabilir. ABD'de yapılan bir araştırma sonucunda, kadın girişimcilerin bağımsızlık arzusu, kendi kararlarını kontrol edebilme arzusu gibi nedenler çekme faktörlerine örnek gösterilmektedir. $\mathrm{Bu}$ kapsamda kadınlar, genel olarak girişimsel hedefleri doğrultusunda iş kurmakta, sadece çok az sayıda kadın ücretli çalışmada yaşanan cinsiyet ayrımından ötürü iş kurduğunu belirtmektedir (Yetim, 2002, s. 79-92).

\section{Kadın Girişimcilerin Karşılaştıkları Sorunlar}

Kadın girişimciliği üzerine yapılan çalışmalarda genel olarak erkek girişimcilerin karşılaştıkları sorunlardan farklı olarak, kadın girişimcilerin cinsiyet farklılıklarından doğan farklı sorunlarla karşı karşıya kaldıkları belirtilmektedir. (Bedük, 2005, s. 113). Kadın girişimciler cinsiyet farklılıklarından ötürü erkek girişimcilere göre birtakım problemlerle baş etmek durumundadırlar. Weiler ve Bernasek tarafından yapılan çalışmada kadın girişimciliği için geçerli olan önemli iki engelden bahsedilmiştir. Bu bağlamda birinci engel kadına yönelik cinsiyet ayrımcıllı̆ı eskiye göre azalmış olmakla birlikte erkekler arasındaki işbirliğinin hala varlığını hissettirmesidir. İkinci önemli engel ise kadınların sahip olduğu işletmelerin erkeklerin sahip oldukları işletmelere kıyasla daha küçük ölçeğe sahip olmalarından ötürü gelişememesidir. Girişimciliğin temelinde varolan erkek egemen yapı nedeniyle, kredi verenler, fon sağlayanlar ve müşterilerin erkek olması sebebi ile kadın girişimciler finansman bulmada ve finansman kaynağına erişmede sıkıntı yaşamaktadırlar (Weiler ve Bernasek, 2001, s. 87). 
Böylece erkeklere oranla daha fazla engellemeye ve toplumsal baskıya maruz kalmaları sebebiyle kadınlar, kamu ve özel sektörlere elde ettiği ürünleri pazarlama imkanına, finansman kaynağı bilgisine, yani bir işletmenin kurulması ve idame ettirilebilinmesi aşamasında gereken bilgilere ulaşmada erkeklere göre daha fazla zorlukla mücadele etmektedir (İlter, 2010, s. 84). Kadın girişimciliği çerçevesinde tamamlayıcı düşünce yapısının sağlanamaması ve örgütlenme problemi, kurumsal farklılıklar ve kadınlara yönelik strateji geliştirme ile ilgili engeller kadın girişimciliğin gelişmesinin önündeki diğer sorunları teşkil etmektedir (İş ve Meslek Sahibi Kadınlar Derneği, 2010, s. 10). Kadınların çalışma yaşamında karşılaştıkları sorunları makro (eğitim düzeyi, sermaye temini) (Sipahi, 1997, s. 67; Hisrich ve Peters, 2002, s. 6; İlter, 2010, s. 94) ve mikro (güvensizlik, tecrübesizlik, rol çatışması, cinsiyet ayrımc1lığ1 (Kutanis ve Alpaslan, 2006, s. 65; Küçük, 2005, s. 46; Saray, 1993, s. 118-119; Gürol, 2000, s. 216-217, İlter, 2010, s. 87-88) sorunlar olarak değerlendirmek mümkündür.

\section{ÇALIŞMA ALANINDA KADIN GÍRIŞ̧IMCILLERIN YERI VE ÇORUM İLINNDE BİR}

\section{ARAŞTIRMA}

\section{Önceki Çalışmalar ve Literatür Taraması}

Yaşar (2017) yaptığı çalışmasında; kadın girişimcilerin gerek iş kurarken, gerekse iş kurma süreci sonrasında yaşadıkları sorunları belirlenmeye çalışmıştır. Karşılaşılan sorunlara çözüm önerisi olarak risk alma konusunu işlemiştir. Sorunların çözümü için daha cesaretli davranmaları gerektiği üzerinde durulmuştur. Bürokratik işlemler konusunda yaşanan sıkıntıların çözümü için, bu konuda destek sağlayan kurum ve kuruluşlardan yardım alarak bir çözüm önerisi oluşturulmasını tavsiye etmiştir. Bazen gelecek planları için başka bir iş koluna yönelmenin veya başka bir bölgeye yatırım yapmanın, işletmenin geleceği bakımından verilen doğru kararlar olduğu sonucu ortaya çıkarılmıştır (Yaşar, 2017, s. 109-110).

Öztürk tarafından 2016 yılında gerçekleştirilen çalışmada Türkiye genelindeki kadın girişimcilerin genel profili çizilmiş, kadınların karşılaştıkları sorunlara çözüm getirilmesi ve engellerin kaldırılmasıyla istihdam olanağı ve buna bağlı olarak toplumun refah seviyesinin artacağından bahsedilmiştir (Öztürk, 2016, s. 2-3).

Soysal, tarafindan 2013 yılında gerçekleştirilen “Türkiye'de Kadın Girişimciler: Engeller ve Firsatlar Bağlamında Bir Değerlendirme" konulu çalışmada; kadınların sosyal ve ekonomik gelişmelerde potansiyel bir güç haline getirilmesi ve ekonomik hayatta erkeklerle beraber çalışmalarını sağlayacak projelere öncelik verilmesi gerektiği mümkün olduğunca vurgulanmıştır (Soysal, 2013, s. 111).

Yetim (2010) tarafından yapılan çalışmada, sermayenin sosyal yapısı olarak, kadın girişimcilerin niteliklerinin ve yeterliliklerinin belirlenmesi amaçlanmıştır. Üzerinde araştırma yapılan 224 kadın girişimci Mersin Esnaf ve Sanatkarlar Odası'na kayıtlıdır. Anket formu sosyal sermaye kaynaklarını hem iş kurma hem de sürdürme aşamasında harekete geçirerek girişimci nitelikleri ile bütünleştiren kadın girişimcilerle yüz yüze olarak yapılmıştır. Bu araştırmaya göre kadınlar şahsi sermayelerini ve borçlanarak elde ettikleri kaynakları girişimcilik faaliyetlerinde kullanmışlardır (Yetim, 2010, s. 79).

Verheul ve Ark tarafından 2006 yilında gerçekleştirilen ülkeler temelinde yapılan incelemede kadın ve erkek girişimcilerin etkisinde kaldığ etkenler General Entrepreneurship Monitor'un 29 ülke için hazırladığ raporlar temel alınarak irdelenmiştir. Yapılan bu çalışmalar sonucunda girişimcilik faaliyetinde bulunan kadın ve erkeklerin faaliyet oranlarına aynı faktörlerin aynı oranda etki yapmasına rağmen, yaşam zevki ve işsizlik gibi değişkenlerin kadın ve erkek girişimciler üzerindeki etkilerinin daha farklı olduğu ortaya konulmuştur (Verheul, 2006, s. 261).

Kibas, tarafından 2005 yılında gerçekleştirilen araştırma dâhilinde girişimcilikte köy kadınlarının zorluk ve firsatlar karşısındaki algıları ve girişimcilikteki başarıları incelenmiştir. Bu inceleme; kadınların başarı faktörleri, işe giriş nedenleri mikro girişimciliğe başlamak için sahip oldukları firsatlar ve bu tür girişimciliğe kalkışan kadınların karşılaştıkları zorlukların neler olduğu konularına cevap sunmuştur. Çalışma, kadınların girişimci olma sebeplerinin başında aile ihtiyaçlarının karşılanmasının geldiğini ve girişimci kadınların kazançlarının tamamını ailelerinin ihtiyaçlarına harcadıklarını ortaya koymuştur. Kadın girişimcilerin başarılı olmalarının arkasında yatan en önemli sebep ise, işin başında ve devamında 
ailelerinden gördükleri destektir. Finans piyasası ve pazarlama durumları hakkında fazla bilgiye sahip olmamaları ile yönetim konusunda yeterli erişim ve tecrübelerinin olmaması gibi konuların ise karşılaştıkları zorlukların başında geldiği görülmüştür (Kibas, 2005, s. 1).

Kutanis ve Hancı tarafından 2004 yılında gerçekleştirilen çalışmada girişimci kadınların sosyal hayat ve girişimlerinde kişisel özgürlüklerini kullanma ve algılamadaki derecelerini belirlemek amaciyla yaptıkları çalışmada hizmet sektöründe faaliyette bulunan yirmibeş kadın girişimci 'Yaşam Öyküsü Araştırması' yöntemiyle incelemiş ve çoğu kadın girişimcinin girişimci olma nedenlerinin kişisel özgürlük elde etmek olduğu, finansal destek konusunda yardım talep ettikleri, girişim faaliyetleri sırasında değişik sorunlara maruz kaldıkları, hedeflerinin çok büyük olduğu, kadınlarının çoğunun evli ve ailelerinin de kendilerinin arkasında olup destek verdikleri görülmüştür (Kutanis ve Hanc1, 2004, s. 2).

\section{Araştırmanın Amacı ve Hipotezleri}

Araştırmada Çorum ilinde bulunan kadın girişimcilerin hem cinsiyete dayalı girişimci özelliklerinin ve niteliklerinin belirlenmesi, hem de üretim sektörü bağlamında değerlendirilmesi amaçlanmıştır. Bu amaç kapsamında Çorum ili içerisindeki kadın girişimcileri üretim sektörüne yönlendirmek amacıyla önerilerde bulunulmuştur.

Hipotez, istatistik biliminde tesadüfi bir değişkenin dağılımı ile ilgili yapılan varsayımdır. Araştırmacının araştırdığı problemdeki değişkenlerin arasında olan ilişkilerden neler beklendiğini ifade etmek, hipotezin görevidir. Sıfir (null) hipotezi Ho olarak ifade edilir ve genelde fark olmadığı tezi üzerine kurulur. Alternatif hipotezler de bu çalışmada test edilmiştir. Alternatif hipotezler istatistiksel analizler sonucunda kabul ya da reddedilen hipotezlerdir. Bu açıklamalar sonucunda yapılan çalışma ile ilgili geliştirilen hipotezler şu şekildedir:

$\mathbf{H}_{1}$ : Girişimcilik faktörlerinin önem düzeyi kadın girişimcilerin medeni durumuna göre anlamlı farkl111k gösterir.

$\mathbf{H}_{2}$ : Girişimcilik faktörlerinin önem düzeyi kadın girişimcilerin yaşına göre anlamlı farklılık gösterir.

$\mathbf{H}_{3}$ : Girişimcilik faktörlerinin önem düzeyi kadın girişimcilerin çocuk sahibi olma durumuna göre anlamlı farklılık gösterir.

$\mathbf{H}_{4}$ : Girişimcilik faktörlerinin önem düzeyi kadın girişimcilerin eğitim durumuna göre anlamlı farklılık gösterir.

H5: Girişimcilik faktörlerinin önem düzeyi kadın girişimcilerin yabancı dil bilme durumuna göre anlamlı farklılık gösterir.

H6: Girişimcilik faktörlerinin önem düzeyi kadın girişimcilerin işletmelerine ait hizmet süresine göre anlamlı farklılık gösterir.

$\mathbf{H}_{7}$ : Girişimcilik faktörlerinin önem düzeyi kadın girişimcilerin iş hayatına giriş biçimine göre anlamlı farkl111k gösterir.

\section{Araştırmanın Yöntemi}

Araştırma, Kütle Basit Tesadüfi Örneklem Yöntemi kullanılarak seçilen 61 kadın girişimciden oluşmaktadır. İlgili veriler KOSGEB İl Müdürlüğü’nden talep edilmiş fakat talebimiz 24/03/2016 tarih ve 6698 sayılı resmi gazetede yer alan "Kişisel Verilerin Korunması Kanunu” ile sınırlandırılmış olduğundan verilerin tablolaştırılmış halinin ilgili birimlerden temini sağlanamadığı için analize dâhil edilen firmalarla ilgili veriler araştırmacının birebir ilişkilerine ve kişisel çabalarına dayanarak elde edilebilmiş ve analize tabi tutulmuştur.

Yukarıda bahsi geçen tarama modeli kullanılarak, bu araştırmayla, üzerinde herhangi bir oynama yapılmadan mevcut durum ortaya konulmaya çalışılmıştır. Çalışmada nicel araştırma yöntemlerinden biri olan anket yöntemi uygulanmıştır. Anket form verileri SPSS 21.0 veri analiz programı dâhilinde kullanılarak gerekli test ve analiz metotları uygulanmıştır. 


\section{Araştırmanın Örneklemi ve Varsayımları}

Araştırmanın uygulama alanı Çorum ili ile sınırlandırılmıştır. Anketi dolduran katılımcıların, demografik bilgileri ve anket sorularından oluşan ölçme araçlarını samimi ve doğru olarak yanttlayacakları varsayılmışı̧ı. Araştırmanın örnekleminin uygulama alanını uygun olarak yansıttı̆̆ varsayımlar arasindadir.

\section{Araştırmanın Bulguları}

65 madde ve 7 alt boyuttan meydana gelen 5'li likert ölçeğinin analiz gerçekleştirmek için yeterli olup olmadığı, örneklem hacminin boyutu ve verilerin tesadüfi dağılımının tespit edilmesi açısından güvenirlik analizi kullanılmıştır. Analiz edilmesi öngörülen testlerin ya da ölçeklerin niteliklerini ve güvenirliklerini tespit etmek üzere bu yöntem kullanılmaktadır. Cronbach's Alpha $(\alpha)$ modeli ile ölçek üzerinde $\mathrm{k}$ sorununun eşit dağılımda bir bütünü içerip içermediği bilgisine ulaşılmıştır. Ölçeğin güvenirliği alfa $(\alpha)$ katsayısı göz önünde bulundurularak şu şekilde yorumlanabilinir: (Ercan ve Kan, 2004: 212);

- $0,00 \leq \alpha<0,40$ ise ölçek güvenilir değildir.

- $0,40 \leq \alpha<0,60$ ise ölçeğin güvenilirliği düşüktür.

- $0,60 \leq \alpha<0,80$ ise ölçek oldukça güvenilirdir.

- $\quad 0,80 \leq \alpha<1,00$ ise ölçek yüksek derecede güvenilir bir ölçektir.

Anketteki her soruya verilen yanıtın dağılımını hesaplamak için Frekans analizi, likert tipi soruların ortalama değerlerini göstermek için ise Descriptive Analizi uygulanmıştır. Üretimde kadın girişimciliği ölçeğinin alt boyutları arasındaki ilişkinin yönü ve şiddetini hesaplamak için Korelasyon Analizi'nden yararlanılmıştır. Korelasyon analizi, iki değiş̧en arasındaki doğrusal ilişkiyi veya bir değişkenin iki veya daha çok değişken ile olan ilişkisini test etmek, varsa bu ilişkinin derecesini ölçmek için kullanılan istatistiki bir yöntemdir. Korelasyon analizinde amaç; değişkenlerden biri değiştiğinde diğer değişkenin ne yönde değiştiğini görmektir. Korelasyon analizi sonucunda, doğru ilişki olup olmadığı ve varsa bu ilişkinin derecesi korelasyon katsayısı ile hesaplanır. Korelasyon katsayısı " $r$ " ile gösterilir ve -1 ile +1 arasında değer alır. $\mathrm{R}$ değeri sıfırdan ne kadar uzaklaşırsa iki değişken arasındaki ilişki de gittikçe güçleşir. Korelasyon katsayısı r "+” değerli ise iki değişken arasında aynı yönde bir ilişki vardır. Eğer r katsayısı "“_" işaretli ise iki değişken arasında ters yönlü bir ilişki vardır.

Kadın girişimciliğin öneminin araştırmaya katılanların demografik bilgilerine göre farklılık gösterip göstermediği $\mathrm{T}$ ve $\mathrm{F}$ testleri ile test edilmiştir. $\mathrm{T}$ (Student) testi, iki örneklem grubu arasında ortalamalar açısından fark olup olmadığını araştırmak amacıyla kullanılır. $\mathrm{T}$ testi, bir gruptaki ortalamanın diğer gruptaki ortalamadan önemli derecede farklı olup olmadığını belirler. $T$ testi için sıfır hipotezi ve alternatif hipotezi aşağıdaki gibidir.

$\mathbf{H}_{\mathbf{0}}$ : İki grubun ortalamaları arasında anlamlı fark yoktur.

$\mathbf{H}_{1}$ : İki grubun ortalamaları arasında anlamlı fark vardır.

Eğer ikiden fazla grubun ortalamaları karşılaştırılacak ise F (Varyans) Testi uygulanır. İkiden fazla grubun ortalamaları arasında anlamlı bir farklılık olup olmadığını test eden F testinin hipotezi aşağıdaki gibidir.

$\mathbf{H}_{0}: \mu 1=\mu 2=\mu 3=\ldots \ldots . .=\mu \mathrm{N} \quad$ Yani ortalamalar arasinda fark yoktur.

$\mathbf{H}_{1}$ : Ortalamalardan en az ikisi arasında anlamlı fark vardır.

$\% 95$ güven düzeyinde yani $\alpha=0,05$ anlamlılık ile test edilen $\mathrm{F}$ ve $\mathrm{T}$ testine göre anlaml1lı sütununda bulunan değer $\mathrm{p}<0,05$ ise $\mathrm{H}_{0}$ hipotezi reddedilir. Aksi durumda $\mathrm{p}>0,05$ ise $\mathrm{H}_{0}$ hipotezi kabul edilir. Yukarıda belirtilen analizler aşağıda tablolar ve grafikler ile gösterilip test sonuçları yorumlanmıştır.

Tablo 1. Güvenilirlik Analizi

\begin{tabular}{|l|r|r|}
\hline Ölçek & Cronbach's Alpha & $\begin{array}{l}\text { Madde } \\
\text { Sayıs }\end{array}$ \\
\hline İş Kurarken Karşılaşıllan Sıkıntıların Önemi & 0,740 & 11 \\
\hline İşletmede Yaşanan Sıkıntıların Önemi & 0,775 & 8 \\
\hline Kadın Girişimcilerin Çalış̧ma Hayatına Katıllmama Sebeplerinin Önemi & 0,723 & 7 \\
\hline
\end{tabular}




\begin{tabular}{|l|r|r|}
\hline İşletmenin Geleceğe Yönelik Planlarının Önemi & 0,740 & 7 \\
\hline İş Kurmak ve İşte Başarılı Olabilmek İçin Önemli Unsurlar & 0,876 & 6 \\
\hline Girişimci Olmadaki Faktörlerin Önemi & 0,702 & 10 \\
\hline En Uygun Yatırım Alanlarının Önemi & 0,935 & 16 \\
\hline
\end{tabular}

Güvenilirlik analizi tablosuna göre; "İş Kurarken Karşılaşılan Sıkıntıların Önemi” boyutu için güvenilirlik katsayısı $\alpha=0,740$ yani oldukça güvenilir, "Işletmede Yaşanan Sıkıntıların Önemi” boyutu için $\alpha=0,775$ yani oldukça güvenilir, "Kadın Girişimcilerin Çalışma Hayatına Katılmama Sebeplerinin Önemi" boyutu için $\alpha=0,723$ yani oldukça güvenilir, "İşletmenin Geleceğe Yönelik Planlarının Önemi" boyutu için $\alpha=0,740$ yani oldukça güvenilir, "İş Kurmak ve İşte Başarılı Olabilmek İçin Önemli Unsurlar" boyutu için $\alpha=0,876$ yani yüksek derecede güvenilir, "Girişimci Olmadaki Faktörlerin Önemi" boyutu için $\alpha=0,702$ yani oldukça güvenilir ve "En Uygun Yatırım Alanlarının Önemi" boyutu için $\alpha=0,935$ yani yüksek derece güvenilir düzeyde bulunmuştur. Bu bağlamda örnek hacminin yapılacak analiz için oldukça uygun olduğu söylenebilir. Yani örnek tesadüfi dağılmıştır. Ölçeklerden soru çıkarmamıza ya da soru sayısını arttırmamız uygun değildir.

Tablo 2. Çorum Kadın Girişimciler Demografik Bilgiler Tablosu

\begin{tabular}{|c|c|c|c|c|}
\hline & & Frekans $(\mathrm{N})$ & Yüzde & Toplam \\
\hline \multirow{2}{*}{$\begin{array}{l}\text { Medeni } \\
\text { Durumu }\end{array}$} & Evli & 41 & $\% 67,2$ & \multirow[t]{2}{*}{$61 / 100$} \\
\hline & Bekâr & 20 & $\% 32,8$ & \\
\hline \multirow[t]{5}{*}{ Yaş Dağılımı } & 25 Yaş Altı & 3 & $\% 4,9$ & \multirow[t]{5}{*}{$61 / 100$} \\
\hline & 25-29 arası & 9 & $\% 14,8$ & \\
\hline & 30-34 aras1 & 12 & $\% 19,7$ & \\
\hline & 35-39 aras1 & 14 & $\% 23$ & \\
\hline & 40 ve üzeri & 23 & $\% 37,7$ & \\
\hline \multirow{2}{*}{$\begin{array}{l}\text { Çocuk Sahibi } \\
\text { Olma Durumu }\end{array}$} & Evet & 45 & $\% 73,8$ & \multirow[t]{2}{*}{$61 / 100$} \\
\hline & Hayır & 16 & $\% 26,2$ & \\
\hline \multirow{5}{*}{$\begin{array}{l}\text { Eğitim } \\
\text { Durumu }\end{array}$} & İlköğretim & 4 & $\% 6,6$ & \multirow[t]{5}{*}{$61 / 100$} \\
\hline & Lise & 26 & $\% 42,6$ & \\
\hline & Önlisans & 7 & $\% 11,5$ & \\
\hline & Lisans & 21 & $\% 34,4$ & \\
\hline & Lisansüstü & 3 & $\% 4,9$ & \\
\hline \multirow{2}{*}{$\begin{array}{ll}\text { Yabanci } & \text { Dil } \\
\text { Bilgisi } & \\
\end{array}$} & Biliyor & 26 & $\% 43,3$ & \multirow[t]{2}{*}{$61 / 100$} \\
\hline & Bilmiyor & 35 & $\% 56,7$ & \\
\hline \multirow{6}{*}{ Hizmet Süresi } & 1 yildan az & 3 & $\% 4,9$ & \multirow{6}{*}{$61 / 100$} \\
\hline & $1-5$ y1l arası & 23 & $\% 37,7$ & \\
\hline & 6-10 y1l arası & 17 & $\% 27,9$ & \\
\hline & $11-15$ yıl aras1 & 5 & $\% 8,2$ & \\
\hline & $16-20$ yıl aras1 & 1 & $\% 1,6$ & \\
\hline & 20 yıldan fazla & 12 & $\% 19,7$ & \\
\hline \multirow{3}{*}{ İş Hayatı } & İş hayatına ilk defa girişimci olarak başladım & 24 & $\% 40,7$ & \multirow{3}{*}{$61 / 100$} \\
\hline & Özel sektörde başka alanda çalıştım & 18 & $\% 27,1$ & \\
\hline & Aynı işi ücretli yaptım & 19 & $\% 32,2$ & \\
\hline
\end{tabular}

Araştırmaya katılan kadın girişimcilerin \%67,2'sini evliler, \%32,8'ini de bekârlar oluşturmaktadır. Araştırmaya katılan kadın girişimcilerin \%4,9'unu 25 yaş ve altı, \%14,8'ini $25-29$ yaş aralığı, \%19,7'sini 30-34 yaş aralığı, \%23'ünün 35-39 yaş aralığı ve \%37,7'sini 40 yaş ve üzerindekiler oluşturmaktadır. Araştırmaya katılan girişimcilerin \%73,8'inin çocuğu varken, \%26,2'sinin çocuğu yoktur. Araştırmaya katılan kadın girişimcilerin eğitim durumlarına bakıldığında \%6,6'sının ilköğretim, \%42,6'sının lise ve dengi, \%11,5'inin önlisans, \%34,4'ünün lisans ve \%4,9'unun lisansüstü eğitime sahip olduğu görülmektedir. Araştırmaya katılan kadın girişimcilerin \%43,3'ü yabancı dil bildiği, \%56,7'si yabancı dil bilmediği anlaşılmaktadır. Araştırmaya katılan kadın girişimcilerin sektörlerine bakıldığında \% 16,4 'ünün kuaför ve kişisel bakım, \%14,8'inin büro hizmetleri, \%14,8'nı tekstil ve hazır giyim, \%13,1'inin restoran ve kafe sektöründe hizmet verdiği görülmektedir.

Araştırmaya katılan kadın girişimcilerin işletmelerine ait hizmet sürelerine bakıldığında \%4,9'unun 1 yıldan daha az, \%37,7'sinin 1-5 y11, \%27,9'unun 6-10 y11, \%8,2'sinin 11-15 y11, \%1,6'sinin 16-20 y11 aralığında ve \%19,7'sinin 20 yılın üzerinde hizmet verdiği görülmektedir. Kadın girişimcilerin \%40,7'si 
iş hayatına ilk defa girişimci olarak başlamıştır. Özel sektörde başka alanda çalışarak başlayanların oranı $\% 27,1$ iken aynı işi ücretli olarak yapanların oranı da \%32,2'dir.

Tablo 3. İşletmeye Yönelik İfadeler

\begin{tabular}{|c|c|c|c|}
\hline & & Evet & Hayır \\
\hline \multirow{2}{*}{ Sektöre atılırken profesyonel yardım aldınız mı? } & $\mathrm{f}$ & 25 & 34 \\
\hline & $\%$ & 42,4 & 57,6 \\
\hline \multirow{2}{*}{ Çalışanlarınıza eğitim veriyor ya da verdiriyor musunuz? } & $\mathrm{f}$ & 38 & 22 \\
\hline & $\%$ & 63,3 & 36,7 \\
\hline \multirow{2}{*}{ İşlerinizde internetten faydalanıyor musunuz? } & $\mathrm{f}$ & 57 & 3 \\
\hline & $\%$ & 95,0 & 5,0 \\
\hline \multirow{2}{*}{ İşletmenizin web sayfası var mıdır? } & $\mathrm{f}$ & 35 & 25 \\
\hline & $\%$ & 58,3 & 41,7 \\
\hline \multirow{2}{*}{ İşyerinizde yetiştirilmek üzere eleman alıyor musunuz? } & $\mathrm{f}$ & 45 & 13 \\
\hline & $\%$ & 77,6 & 22,4 \\
\hline
\end{tabular}

Kadın girişimcilerin \%42,4'ü sektöre atılırken profesyonel yardım alırken \%57,6'sı profesyonel yardım almamıştır. Çalışanlarına eğitim veren ya da verdiriyor olanların oranı $\% 63,3$ 'tür. İşletmelerin $\% 95$ 'i internetten faydalanmakta, \%58,3'ünün de web sayfası bulunmaktadır. İşletmelerin \%77,6's1 da yetiştirilmek üzere eleman almaktadır.

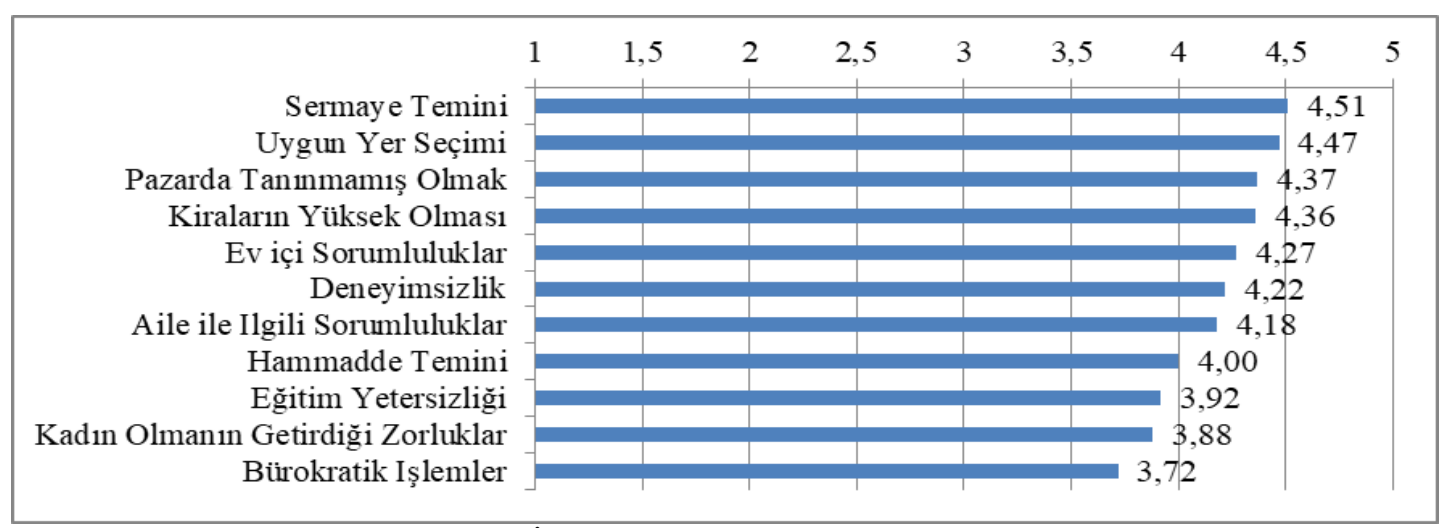

Şekil 1. İş Kurarken Karşılaşılan Sıkıntılar

Kadın girişimcilerin iş kurarken karşılaştığı en önemli sıkıntı sermaye temini $(4,51)$ olmuştur. Uygun yer seçimi $(4,47)$ ikinci en önemli sıkıntı olurken, pazarda tanınmamış olmak $(4,37)$ üçüncü en önemli sorun olmuştur.

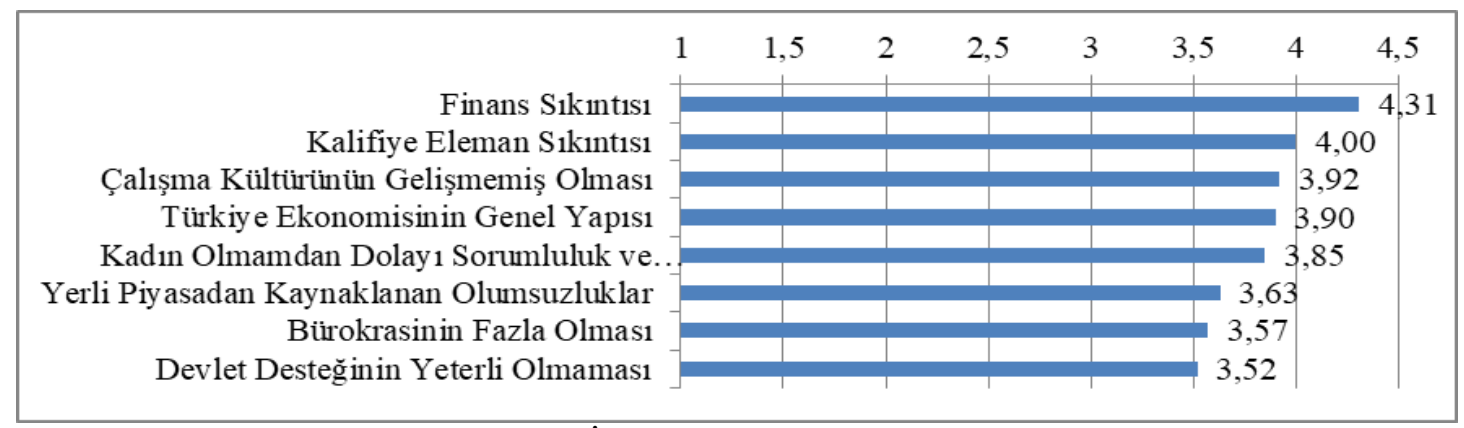

Şekil 2. İşletmede Yaşanan Sorunlar

İşletmelerde yaşanan en önemli sıkıntı finans sıkıntısıdır (4,31). Finans sıkıntısını daha sonra sırasıyla kalifiye eleman sıkıntısı $(4,00)$, çalışma kültürünün gelişmemiş olması $(3,92)$, Türkiye ekonomisinin genel yapısı $(3,90)$ üçüncü sırada yer almaktadır. 


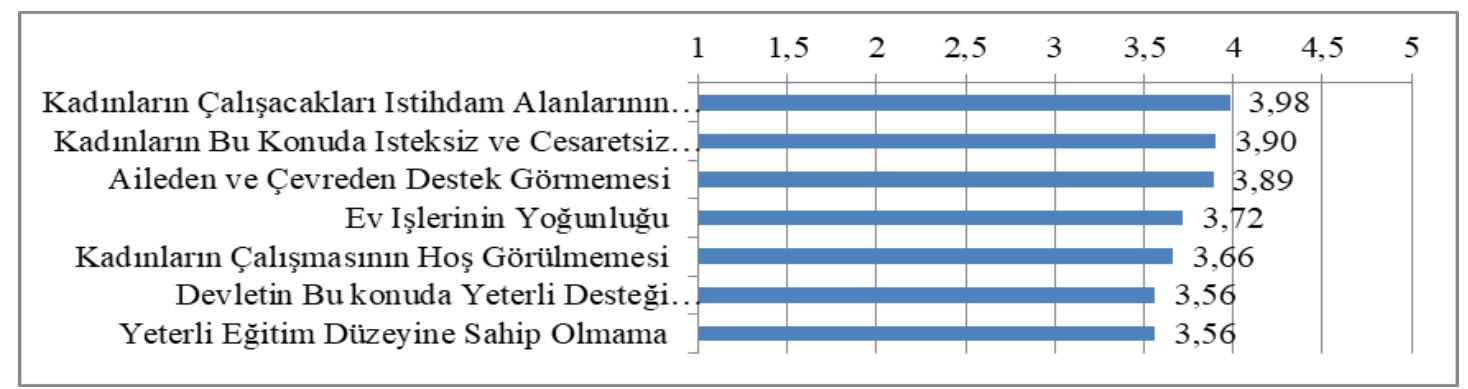

Şekil 3. Kadın Girişimcilerin Çalışma Hayatına Katılamama Sebepleri

Kadınların çalışacakları istihdam alanların yetersiz olması $(3,98)$ kadın girişimcilerine göre kadınların çalışma hayatına katılamamasının en önemli nedenidir. Kadınların girişimcilikte isteksiz ve cesaretsiz olması $(3,90)$ ve aileden ve çevreden destek gelmemesi $(3,89)$ kadınların çalışma hayatına girememesinin diğer önemli sebepleri olarak görülmektedir.

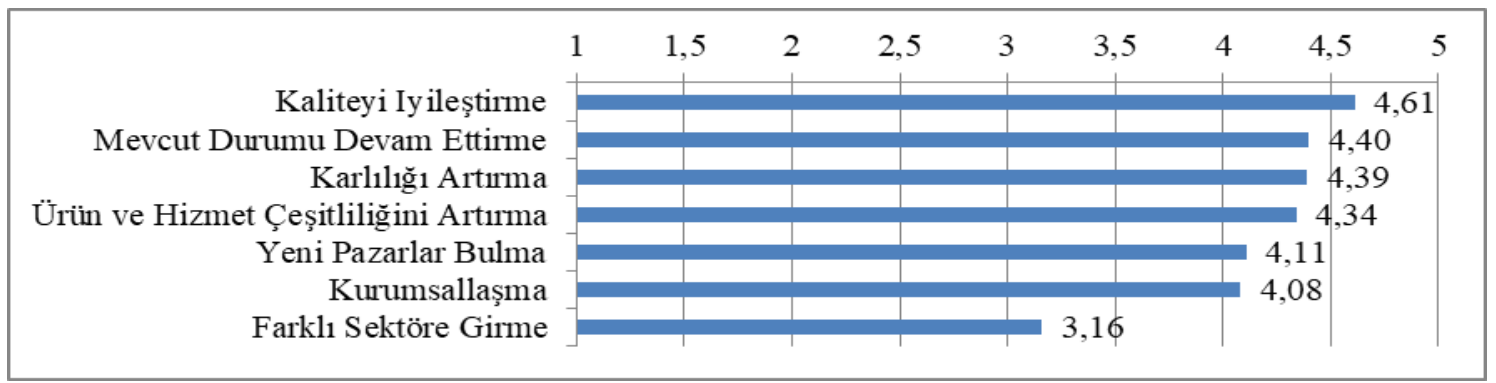

Şekil 4. İşletmelerin Geleceğe Yönelik Planları

İşletmelerin geleceğe yönelik en önemli planı 4,61 ortalama puan ile kaliteyi iyileştirmek olarak düşünülmektedir. Mevcut durumu devam ettirme $(4,40)$ ve karlılığı arttırma $(4,39)$ diğer önemli unsurlardır.

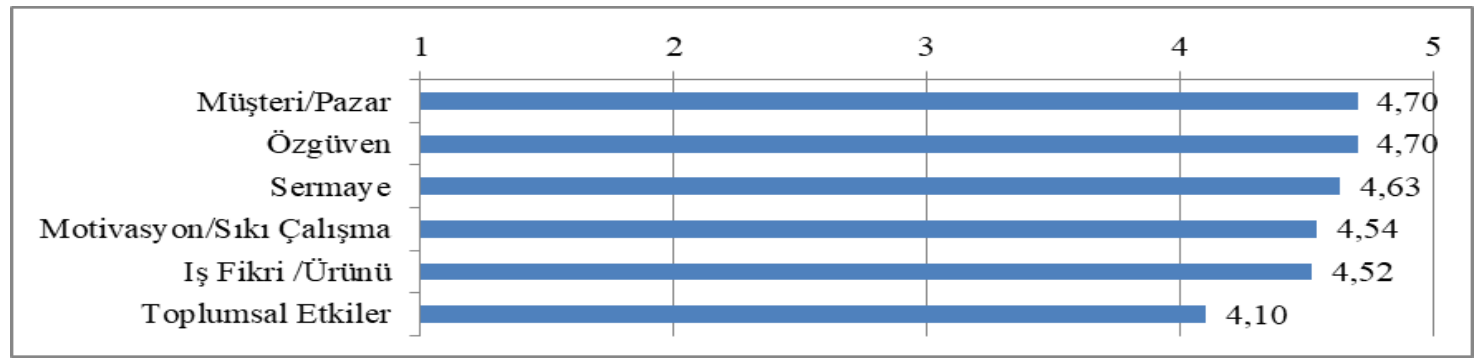

Şekil 5. İş Kurmak ve Başarılı Olmak İçin Unsurlar

Kadın girişimcilere göre iş sahibi olmak ve bu işte verimli ve başarılı olmak için en önemli unsur müşteri/pazar $(4,70)$ ve özgüvendir $(4,70)$. Sermaye $(4,63)$, motivasyon $(4,54)$ ve iş fikri/ürün de oldukça önemli görülmektedir.

\begin{tabular}{|c|c|c|c|c|c|c|c|}
\hline & 1,5 & 2 & 2,5 & 3,5 &, 5 & 4,5 & 5 \\
\hline \multicolumn{8}{|l|}{ Üretken ve Verimli Olma Isteği } \\
\hline \multicolumn{8}{|l|}{ Bağımsız ve Kendi Işinde Çalışma Isteği } \\
\hline \multicolumn{8}{|l|}{ Ekonomik Özgürlüğünüu Sağlayabilme } \\
\hline \multicolumn{8}{|l|}{ Eğitim ya da Tecrübeyi Değerlendirme } \\
\hline \multicolumn{8}{|l|}{ Ekonomik Şartlarm Yetersizliği } \\
\hline Aileye Ek Gelir Sağlayabilme Isteği & & & & & & 4,07 & \\
\hline Kamu Sektöründe Çalıșma Standartlarının.. & & & & & 3,56 & & \\
\hline Başka Iş Bulamama Kayg gisı & & & & & 3,52 & & \\
\hline Ücretli ve Mesai Gerektiren Işe Ailemin Izin.. & & & & 2,97 & & & \\
\hline İșletmenin Aileden Devralınması & & & & 2,84 & & & \\
\hline
\end{tabular}

Şekil 6. Girişimci Olmadaki Faktörler 
Üretken ve verimli olma isteği $(4,67)$ kadın girişimcilerin girişimci olmasındaki en önemli faktördür. Bağımsız ve kendi işinde çalışma isteği $(4,53)$ ikinci en önemli faktör, ekonomik özgürlüğünü sağlayabilme $(4,34)$ üçüncü en önemli faktör olmuştur.

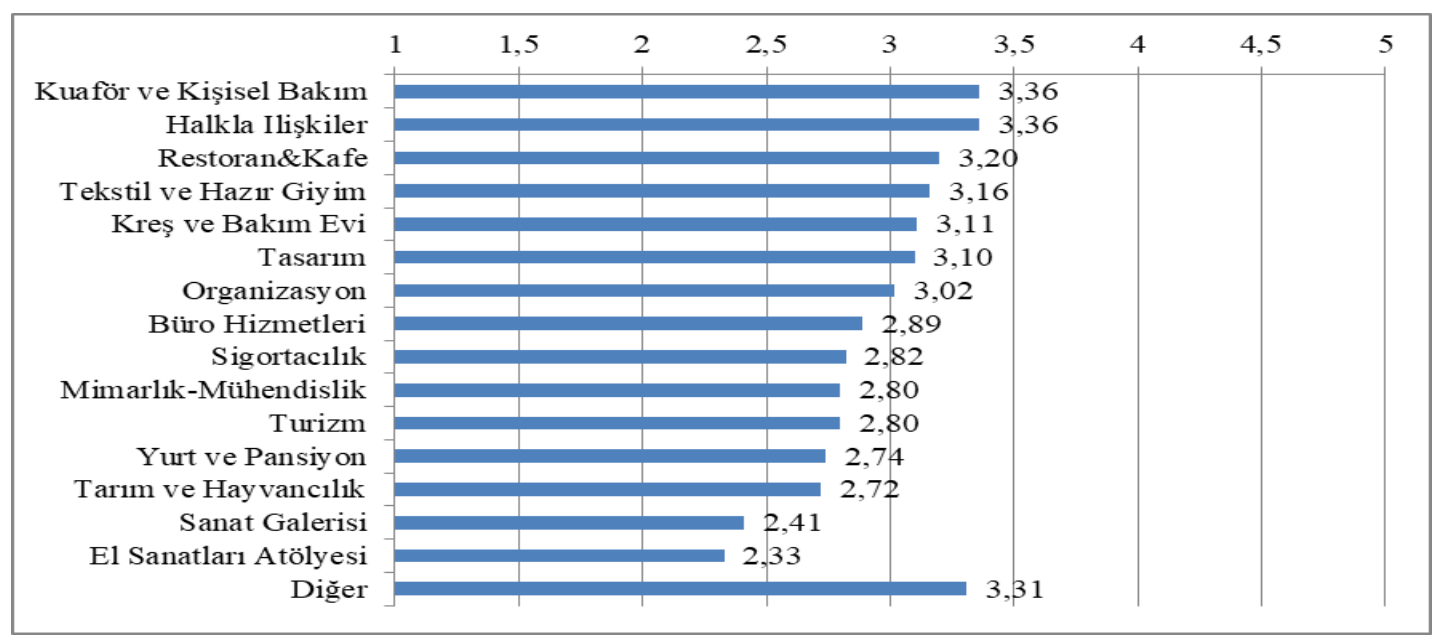

Şekil 7. En Uygun Yatırım Alanları

Kadın girişimcilere göre en uygun yatırım alanı kuaför ve kişisel bakım $(3,36)$ ve halkla ilişkiler $(3,36)$ alanlarıdır. Bunları sırasıyla restoran/cafe $(3,20)$, tekstil ve hazır giyim $(3,16)$, kreş ve bakım evi $(3,11)$, tasarım alanları $(3,10)$ izlemektedir.

Tablo 4. Girişimcilik Boyutları Arasındaki İlişkiyi İnceleyen Korelasyon Analizi

\begin{tabular}{|c|c|c|c|c|c|c|c|c|}
\hline & & 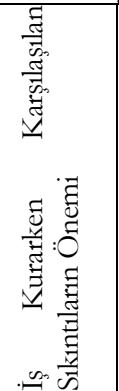 & 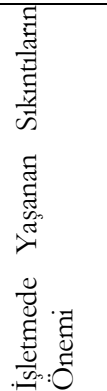 & 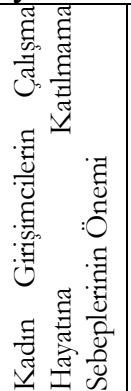 & 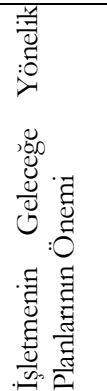 & 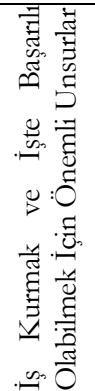 & 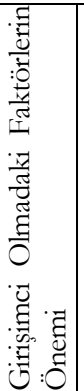 & 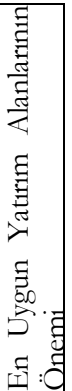 \\
\hline \multirow{2}{*}{$\begin{array}{l}\text { İş Kurarken } \\
\text { Karşılaşılan Sıkıntılar }\end{array}$} & $r$ & 1 & & & & & & \\
\hline & $\mathrm{P}$ & & & & & & & \\
\hline \multirow{2}{*}{$\begin{array}{l}\text { Isşletmede Yaşanan } \\
\text { Sıkıntıların Önemi }\end{array}$} & $\mathrm{r}$ &, $692(* *)$ & 1 & & & & & \\
\hline & $\mathrm{P}$ & , 000 & & & & & & \\
\hline \multirow{2}{*}{$\begin{array}{l}\text { Kadın Girişimcilerin Çalışma } \\
\text { Hayatına Katılmama Sebeplerinin Önemi }\end{array}$} & $\mathrm{r}$ &, $542(* *)$ &, $590(* *)$ & 1 & & & & \\
\hline & $\mathrm{P}$ & , 000 &, 000 & & & & & \\
\hline \multirow{2}{*}{$\begin{array}{l}\text { İ̀sletmenin Geleceğe } \\
\text { Yönelik Planlarının Önemi }\end{array}$} & $\mathrm{r}$ &, $447(* *)$ &, $405(* *)$ &, $420(* *)$ & 1 & & & \\
\hline & $\mathrm{P}$ & , 000 & ,001 & , 001 & & & & \\
\hline \multirow{2}{*}{$\begin{array}{l}\text { İş Kurmak ve İşste Başarilı } \\
\text { Olabilmek İçin Önemli Unsurlar }\end{array}$} & $\mathrm{r}$ &, $509(* *)$ & ,474(**) & ,494(**) & ,422(**) & 1 & & \\
\hline & $\mathrm{P}$ & ,000 & ,000 & ,000 & ,001 & & & \\
\hline \multirow{2}{*}{$\begin{array}{l}\text { Girişimci Olmadaki } \\
\text { Faktörlerin Önemi }\end{array}$} & $\mathrm{r}$ &, $455(* *)$ & ,372(**) & ,486(**) & 238 & ,296(*) & 1 & \\
\hline & $\mathrm{P}$ & , 000 & ,003 & , 000 & 065 & , 020 & & \\
\hline \multirow{2}{*}{$\begin{array}{l}\text { En Uygun Yatırım } \\
\text { Alanlarının Önemi }\end{array}$} & $\mathrm{r}$ &, $426(* *)$ &, $531(* *)$ & ,431(**) &, $512(* *)$ & 202 & ,225 & 1 \\
\hline & $\mathrm{P}$ & ,001 & ,000 & ,001 & , 000 &, 118 & ,082 & \\
\hline
\end{tabular}

** 0,01 Seviyesinde korelasyonun anlamlı olduğu seviye (2-tailed).

* 0,05 Seviyesinde korelasyonun anlamlı olduğu seviye (2-tailed).

Yukarıdaki korelasyon analizine göre tüm korelasyon değerleri pozitif yönlü bulunmuştur. Yani girişimcilik boyutları arasında aynı yönlü bir ilişki vardır. İş kurarken karşılaşılan sıkıntılar arttıkça işletmelerde yaşanan sıkıntının önemi de artmakta, kadın girişimcilerin çalışma hayatına katılamama sebeplerinin önemi de artmakta, işletmenin geleceğe yönelik planlarının önemi, iş kurmak ve işte başarılı olmanın önemi, girişimci olmadaki faktörlerin önemi ve en uygun yatırım alanlarının önemi de artmaktadır. 
Tablo 5. Girişimcilik Faktörlerinin Önem Düzeyinin Medeni Duruma Göre Farklılığını İnceleyen T Testi

\begin{tabular}{|c|c|c|c|c|c|c|}
\hline & $\begin{array}{l}\text { Medeni } \\
\text { Durum }\end{array}$ & $\begin{array}{l}\text { Kişi } \\
\text { Sayıs }\end{array}$ & Ortalama & $\begin{array}{l}\text { Std. } \\
\text { Sapma }\end{array}$ & $\mathrm{t}$ & $\begin{array}{l}\text { Anlamllilk } \\
\text { (P) }\end{array}$ \\
\hline \multirow{2}{*}{ İş Kurarken Karşılaşılan Sıkıntıların Önemi } & Evli & 41 & 4,1644 & 47711 & \multirow{2}{*}{,- 213} & \multirow{2}{*}{0,832} \\
\hline & Bekâr & 20 & 4,1909 & ,41387 & & \\
\hline \multirow{2}{*}{ İşletmede Yaşanan Sıkıntıların Önemi } & Evli & 41 & 3,9103 & 54263 & \multirow{2}{*}{1,468} & \multirow{2}{*}{0,147} \\
\hline & Bekâr & 20 & 3,7063 & ,43163 & & \\
\hline \multirow{2}{*}{$\begin{array}{llll}\text { Kadın Girişimcilerin } & \text { Çalışma } & \text { Hayatına } & \text { Katılmama } \\
\text { Sebeplerinin Önemi }\end{array}$} & Evli & 41 & 3,8043 & ,55101 & \multirow{2}{*}{,972 } & \multirow{2}{*}{0,335} \\
\hline & Bekâr & 20 & 3,6500 &, 64302 & & \\
\hline \multirow{2}{*}{ İşletmenin Geleceğe Yönelik Planlarının Önemi } & Evli & 41 & 4,1823 & ,60524 & \multirow{2}{*}{, 545} & \multirow{2}{*}{0,588} \\
\hline & Bekâr & 20 & 4,1000 & 42757 & & \\
\hline \multirow{2}{*}{ İş Kurmak ve İşte Başarılı Olabilmek İçin Önemli Unsurlar } & Evli & 41 & 4,5447 & ,59631 & \multirow{2}{*}{,180 } & \multirow{2}{*}{0,858} \\
\hline & Bekâr & 20 & 4,5167 & ,51838 & & \\
\hline \multirow{2}{*}{ Girişimci Olmadaki Faktörlerin Önemi } & Evli & 41 & 3,9648 & 47346 & \multirow{2}{*}{1,969} & \multirow{2}{*}{0,050} \\
\hline & Bekâr & 20 & 3,7033 &, 51355 & & \\
\hline \multirow{2}{*}{ En Uygun Yatırım Alanlarının Önemi } & Evli & 41 & 3,0078 & 1,03557 & \multirow{2}{*}{ 656 } & \multirow{2}{*}{0,514} \\
\hline & Bekâr & 20 & 2,8294 & 90864 & & \\
\hline
\end{tabular}

$\mathbf{H}_{0}$ : Girişimcilik faktörlerinin önem düzeyi kadın girişimcilerin medeni durumuna göre anlamlı farkl111k göstermez.

$\mathbf{H}_{1}$ : Girişimcilik faktörlerinin önem düzeyi kadın girişimcilerin medeni durumuna göre anlamlı farkl11ı gösterir.

Girişimci olmadaki faktörlerin önemi evli girişimcilerde $(3,9648)$ bekâr girişimcilere göre $(3,7033)$ daha yüksek düzeydedir. Anlamlılık değerinin $\mathrm{p}=0,050 \leq 0,05$ olmasından dolayı girişimci olmadaki faktörler için $\mathrm{H}_{0}$ hipotezi reddedilir. Yani, girişimci olmadaki faktörlerin önemi kadın girişimcilerin medeni durumuna göre anlamlı farkl1lık gösterir.

Diğer faktörler için anlamlılık değerlerinin $\mathrm{p}>0,05$ olmasından dolayı diğer faktörler kadın girişimcilerin medeni durumuna göre anlamlı farklılık göstermemektedir.

Tablo 6. Girișimcilik Faktörlerinin Önem Düzeyinin Yaşa Göre Farklılığını İnceleyen F Testi

\begin{tabular}{|c|c|c|c|c|c|c|}
\hline & Yaş & $\begin{array}{l}\text { Kişi } \\
\text { Sayis1 }\end{array}$ & Ortalama & $\begin{array}{l}\text { Std. } \\
\text { Sapma }\end{array}$ & F & $\begin{array}{l}\text { Anlamlilik } \\
(\mathrm{P})\end{array}$ \\
\hline \multirow{5}{*}{ İş Kurarken Karşılaşılan Sıkıntıların Önemi } & 25-29 aras1 & 9 & 4,3333 & ,40401 & \multirow{5}{*}{2,784} & \multirow{5}{*}{0,050} \\
\hline & $30-34$ aras1 & 12 & 4,0303 & ,41267 & & \\
\hline & 35-39 aras1 & 17 & 4,3918 & ,35726 & & \\
\hline & 40 ve üzeri & 23 & 4,0348 & ,49514 & & \\
\hline & Toplam & 61 & 4,1664 & ,45527 & & \\
\hline \multirow{5}{*}{ İşletmede Yaşanan Sıkıntıların Önemi } & $25-29$ arasi & 9 & 3,9444 &, 50432 & \multirow{5}{*}{, 517} & \multirow{5}{*}{0,672} \\
\hline & 30-34 aras1 & 12 & 3,7500 & ,44274 & & \\
\hline & 35-39 aras1 & 17 & 3,9605 & ,44465 & & \\
\hline & 40 ve üzeri & 23 & 3,8043 & ,59571 & & \\
\hline & Toplam & 61 & 3,8525 & ,51277 & & \\
\hline \multirow{5}{*}{$\begin{array}{l}\text { Kadın Girişimcilerin Çalışma Hayatına } \\
\text { Katılmama Sebeplerinin Önemi }\end{array}$} & $25-29$ aras 1 & 9 & 3,7778 & ,80214 & \multirow{5}{*}{1,002} & \multirow{5}{*}{0,399} \\
\hline & $30-34$ aras1 & 12 & 3,6190 & ,30048 & & \\
\hline & 35-39 aras1 & 17 & 3,9592 & ,37349 & & \\
\hline & 40 ve üzeri & 23 & 3,6698 & ,65757 & & \\
\hline & Toplam & 61 & 3,7459 & ,56877 & & \\
\hline \multirow{5}{*}{$\begin{array}{l}\text { İşletmenin Geleceğe Yönelik Planlarının } \\
\text { Önemi }\end{array}$} & $25-29$ aras1 & 9 & 4,1587 &, 51232 & \multirow{5}{*}{,485 } & \multirow{5}{*}{0,694} \\
\hline & 30-34 aras1 & 12 & 4,1548 &, 53264 & & \\
\hline & 35-39 aras1 & 17 & 4,2755 & ,55318 & & \\
\hline & 40 ve üzeri & 23 & 4,0455 & ,60872 & & \\
\hline & Toplam & 61 & 4,1412 &, 55911 & & \\
\hline \multirow{5}{*}{$\begin{array}{l}\text { İş̧ Kurmak ve İşte Başarılı Olabilmek İçin } \\
\text { Önemli Unsurlar }\end{array}$} & 25-29 aras1 & 9 & 4,4630 & ,43921 & \multirow{5}{*}{2,152} & \multirow{5}{*}{0,104} \\
\hline & 30-34 aras1 & 12 & 4,4167 &, 53418 & & \\
\hline & 35-39 aras1 & 17 & 4,8571 & ,24335 & & \\
\hline & 40 ve üzeri & 23 & 4,4420 & ,67907 & & \\
\hline & Toplam & 61 & 4,5402 & ,55348 & & \\
\hline
\end{tabular}




\begin{tabular}{|c|c|c|c|c|c|c|}
\hline \multirow{5}{*}{ Girişimci Olmadaki Faktörlerin Önemi } & $25-29$ arasi & 9 & 3,9444 & ,40654 & \multirow{5}{*}{,385 } & \multirow{5}{*}{0,765} \\
\hline & 30-34 aras1 & 12 & 3,8250 &, 50114 & & \\
\hline & 35-39 aras1 & 17 & 3,9786 &, 50563 & & \\
\hline & 40 ve üzeri & 23 & 3,8271 & ,49638 & & \\
\hline & Toplam & 61 & 3,8814 & 47946 & & \\
\hline \multirow{5}{*}{ En Uygun Yatırım Alanlarının Önemi } & $25-29$ arasi & 9 & 3,3819 & 80249 & \multirow{5}{*}{2,371} & \multirow{5}{*}{0,081} \\
\hline & $30-34$ aras1 & 12 & 2,3153 & ,91923 & & \\
\hline & $35-39$ aras1 & 17 & 3,0846 & 1,18955 & & \\
\hline & 40 ve üzeri & 23 & 2,9688 & 91265 & & \\
\hline & Toplam & 61 & 2,9257 & 1,00793 & & \\
\hline
\end{tabular}

$\mathbf{H}_{\mathbf{0}}$ : Girişimcilik faktörlerinin önem düzeyi kadın girişimcilerin yaşına göre anlamlı farklılık göstermez. $\mathbf{H}_{2}$ : Girişimcilik faktörlerinin önem düzeyi kadın girişimcilerin yaşına göre anlamlı farklılık gösterir.

İş kurarken karşılaşılan sıkıntıların önemi 35-39 yaş arası kadın girişimcilerde $(4,3918)$ en yüksek düzeyde algılanmış, 30-34 yaş arası kadınlarda ise $(4,0303)$ diğer girişimcilere göre biraz daha düşük düzeyde algılanmıştır. Anlamlılık değerinin $p=0,050 \leq 0,05$ olmasından dolayı iş kurarken karşılaşılan sıkıntıların önemi için $\mathrm{H}_{0}$ hipotezi reddedilir. Yani, kadın girişimcilerin iş kurarken karşılaştı̆̆ sıkıntılar yaşına göre anlamlı farkl11ık gösterir.

Diğer boyutlar için anlamlılık değerlerinin $\mathrm{p}>0,05$ olmasından dolayı diğer boyutla için $\mathrm{H}_{0}$ kabul edilir. Yani önem düzeyleri kadın girişimcilerin yaşına göre anlamlı farklılık göstermez.

Tablo 7. Girişimcilik Faktörlerinin Önem Düzeyinin Çocuk Sahibi Olma Duruma Göre Farklılığını İnceleyen T Testi

\begin{tabular}{|c|c|c|c|c|c|c|}
\hline & $\begin{array}{l}\text { Çocuk } \\
\text { Var mı? } \\
\end{array}$ & $\begin{array}{l}\text { Kişi } \\
\text { Sayis1 } \\
\end{array}$ & Ortalama & $\begin{array}{l}\text { Std. } \\
\text { Sapma }\end{array}$ & $\mathrm{t}$ & $\begin{array}{l}\text { Anlamllikk } \\
\text { (P) }\end{array}$ \\
\hline \multirow{2}{*}{ İş Kurarken Karşılaşılan Sıkıntıların Önemi } & Evet & 45 & 4,1397 & ,47487 & \multirow{2}{*}{$-0,963$} & \multirow{2}{*}{0,339} \\
\hline & Hayır & 16 & 4,2670 & ,38779 & & \\
\hline \multirow{2}{*}{ İşletmede Yaşanan Sıkıntıların Önemi } & Evet & 45 & 3,9016 &, 52121 & \multirow{2}{*}{1,497} & \multirow{2}{*}{0,140} \\
\hline & Hayır & 16 & 3,6797 & ,47207 & & \\
\hline \multirow{2}{*}{$\begin{array}{l}\text { Kadın Girişimcilerin Çalışma Hayatına Katılmama } \\
\text { Sebeplerinin Önemi }\end{array}$} & Evet & 45 & 3,7963 &, 53648 & \multirow{2}{*}{0,958} & \multirow{2}{*}{0,342} \\
\hline & Hayır & 16 & 3,6339 & 69979 & & \\
\hline \multirow{2}{*}{ İşletmenin Geleceğe Yönelik Planlarının Önemi } & Evet & 45 & 4,1598 &, 59702 & \multirow{2}{*}{0,105} & \multirow{2}{*}{0,917} \\
\hline & Hayır & 16 & 4,1429 & ,41074 & & \\
\hline \multirow{2}{*}{ İş Kurmak ve İşte Başarılı Olabilmek İçin Önemli Unsurlar } & Evet & 45 & 4,5259 &, 58921 & \multirow{2}{*}{$-0,220$} & \multirow{2}{*}{0,827} \\
\hline & Hayır & 16 & 4,5625 &, 51953 & & \\
\hline \multirow{2}{*}{ Girişimci Olmadaki Faktörlerin Önemi } & Evet & 45 & 3,9079 & ,49694 & \multirow{2}{*}{0,756} & \multirow{2}{*}{0,453} \\
\hline & Hayır & 16 & 3,7979 &, 50910 & & \\
\hline \multirow{2}{*}{ En Uygun Yatırım Alanlarının Önemi } & Evet & 45 & 2,9519 & 1,05933 & \multirow{2}{*}{0,034} & \multirow{2}{*}{0,973} \\
\hline & Hayır & 16 & 2,9419 & ,80142 & & \\
\hline
\end{tabular}

$\mathbf{H}_{\mathbf{0}}$ : Girişimcilik faktörlerinin önem düzeyi kadın girişimcilerin çocuk sahibi olma durumuna göre anlamlı farklılık göstermez.

$\mathbf{H}_{3}$ : Girişimcilik faktörlerinin önem düzeyi kadın girişimcilerin çocuk sahibi olma durumuna göre anlamlı farklılık gösterir.

Tüm girişimcilik faktörleri için anlamlılık değerlerinin $\mathrm{p}>0,05$ olmasından dolayı tüm faktörler için $\mathrm{H}_{0}$ hipotezi kabul edilir. Yani, girişimcilik faktörlerinin önem düzeyi kadın girişimcilerin çocuk sahibi olma durumuna göre anlamlı farkl111k göstermez. 
Tablo 8. Girişimcilik Faktörlerinin Önem Düzeyinin Eğitim Durumuna Göre Farklılığını İnceleyen F Testi

\begin{tabular}{|c|c|c|c|c|c|c|}
\hline & $\begin{array}{l}\text { Ë̆itim } \\
\text { Durumu }\end{array}$ & $\begin{array}{l}\text { Kişi } \\
\text { Sayıs1 }\end{array}$ & Ortalama & $\begin{array}{l}\text { Std. } \\
\text { Sapma }\end{array}$ & $\mathrm{F}$ & $\begin{array}{l}\text { Anlamlilik } \\
\text { (P) }\end{array}$ \\
\hline \multirow{4}{*}{$\begin{array}{l}\text { İş Kurarken Karşılaşılan } \\
\text { Sıkıntıların Önemi }\end{array}$} & İlköğretim & 8 & 4,2318 & ,70502 & \multirow{4}{*}{0,286} & \multirow{4}{*}{0,753} \\
\hline & Lise ve dengi & 32 & 4,1420 & ,42801 & & \\
\hline & Lisans ve lisansüstü & 21 & 4,0260 & ,43190 & & \\
\hline & Toplam & 61 & 4,1297 & ,45065 & & \\
\hline \multirow{4}{*}{$\begin{array}{l}\text { İşletmede Yaşanan } \\
\text { Sıkıntıların Önemi }\end{array}$} & İlköğretim & 8 & 3,9375 & ,97093 & \multirow{4}{*}{0,648} & \multirow{4}{*}{0,530} \\
\hline & Lise ve dengi & 32 & 3,7308 &, 44257 & & \\
\hline & Lisans ve lisansüstü & 21 & 3,5714 & ,47794 & & \\
\hline & Toplam & 61 & 3,7230 &, 51212 & & \\
\hline \multirow{4}{*}{$\begin{array}{l}\text { Kadın Girişimcilerin Çalışma } \\
\text { Hayatına } \\
\text { Katılmama Sebeplerinin Önemi }\end{array}$} & İlköğretim & 8 & 3,6071 &, 75930 & \multirow{4}{*}{0,129} & \multirow{4}{*}{0,879} \\
\hline & Lise ve dengi & 32 & 3,7738 & ,63622 & & \\
\hline & Lisans ve lisansüstü & 21 & 3,7755 & ,45816 & & \\
\hline & Toplam & 61 & 3,7561 & 60571 & & \\
\hline \multirow{4}{*}{$\begin{array}{l}\text { İşletmenin Geleceğe Yönelik } \\
\text { Planlarının Önemi }\end{array}$} & İlköğretim & 8 & 4,7143 & ,34993 & \multirow{4}{*}{2,218} & \multirow{4}{*}{0,124} \\
\hline & Lise ve dengi & 32 & 4,0678 &, 58059 & & \\
\hline & Lisans ve lisansüstü & 21 & 4,0612 & ,66933 & & \\
\hline & Toplam & 61 & 4,1364 & ,60047 & & \\
\hline \multirow{4}{*}{$\begin{array}{l}\text { İş Kurmak ve İşte Başarılı } \\
\text { Olabilmek İçin Önemli Unsurlar }\end{array}$} & İlköğretim & 8 & 4,4167 & ,68718 & \multirow{4}{*}{0,500} & \multirow{4}{*}{0,611} \\
\hline & Lise ve dengi & 32 & 4,4551 & ,67587 & & \\
\hline & Lisans ve lisansüstü & 21 & 4,7143 & ,36911 & & \\
\hline & Toplam & 61 & 4,5000 &, 62485 & & \\
\hline \multirow{4}{*}{$\begin{array}{l}\text { Girişimci Olmadaki } \\
\text { Faktörlerin Önemi }\end{array}$} & İlköğretim & 8 & 4,1250 &, 45000 & \multirow{4}{*}{0,374} & \multirow{4}{*}{0,691} \\
\hline & Lise ve dengi & 32 & 3,9316 &, 40433 & & \\
\hline & Lisans ve lisansüstü & 21 & 3,9429 & ,45774 & & \\
\hline & Toplam & 61 & 3,9547 & ,41105 & & \\
\hline \multirow{4}{*}{$\begin{array}{l}\text { En Uygun Yatırım } \\
\text { Alanlarının Önemi }\end{array}$} & İlköğretim & 8 & 3,3813 & ,90493 & \multirow{4}{*}{1,008} & \multirow{4}{*}{0,375} \\
\hline & Lise ve dengi & 32 & 2,7833 & ,92416 & & \\
\hline & Lisans ve lisansüstü & 21 & 2,5851 & ,86388 & & \\
\hline & Toplam & 61 & 2,8105 & ,91233 & & \\
\hline
\end{tabular}

$\mathbf{H}_{\mathbf{0}}$ : Girişimcilik faktörlerinin önem düzeyi kadın girişimcilerin eğitim durumuna göre anlamlı farklılık göstermez.

$\mathbf{H}_{4}$ : Girişimcilik faktörlerinin önem düzeyi kadın girişimcilerin eğitim durumuna göre anlamlı farklılık gösterir.

Girişimcilik faktörlerinin kadın girişimcilerin eğitim durumuna göre farklılık gösterip göstermediğini test etmek amaciyla yapılan $F$ testi sonucuna göre anlamlılık değerlerinin $p>0,05$ olmasından dolayı tüm faktörler için $\mathrm{H}_{0}$ hipotezi kabul edilir. Yani, girişimcilik faktörlerinin önem düzeyi kadın girişimcilerin eğitim durumuna göre anlamlı farklılık göstermez.

Tablo 9. Girişimcilik Faktörlerinin Önem Düzeyinin Yabancı Dil Bilme Duruma Göre Farklılığını Inceleyen T Testi

\begin{tabular}{|c|c|c|c|c|c|c|}
\hline & $\begin{array}{l}\text { Yabanc1 } \\
\text { Dil }\end{array}$ & $\begin{array}{l}\text { Kişi } \\
\text { Say1s1 }\end{array}$ & Ortalama & $\begin{array}{l}\text { Std. } \\
\text { Sapma }\end{array}$ & $\mathrm{t}$ & $\begin{array}{l}\text { Anlamlilik } \\
\text { (P) }\end{array}$ \\
\hline \multirow{2}{*}{$\begin{array}{l}\text { İş Kurarken Karşılaşılan } \\
\text { Sıkıntıların Önemi }\end{array}$} & Biliyorum & 26 & 4,2308 & ,34901 & \multirow{2}{*}{1,003} & \multirow{2}{*}{0,320} \\
\hline & Bilmiyorum & 35 & 4,1127 &, 51658 & & \\
\hline \multirow{2}{*}{$\begin{array}{l}\text { İssletmede Yaşanan } \\
\text { Sıkıntıların Önemi }\end{array}$} & Biliyorum & 26 & 4,0096 & ,35518 & \multirow{2}{*}{2,491} & \multirow{2}{*}{0,016} \\
\hline & Bilmiyorum & 35 & 3,6933 &, 56750 & & \\
\hline \multirow{2}{*}{$\begin{array}{l}\text { Kadın Girişimcilerin Çalışma } \\
\text { Hayatına } \\
\text { Katılmama Sebeplerinin Önemi }\end{array}$} & Biliyorum & 26 & 3,8407 & 60922 & \multirow{2}{*}{1,150} & \multirow{2}{*}{0,255} \\
\hline & Bilmiyorum & 35 & 3,6674 &, 55423 & & \\
\hline \multirow{2}{*}{$\begin{array}{l}\text { İşletmenin Geleceğe Yönelik } \\
\text { Planlarının Önemi }\end{array}$} & Biliyorum & 26 & 4,1612 & ,47007 & \multirow{2}{*}{0,246} & \multirow{2}{*}{0,807} \\
\hline & Bilmiyorum & 35 & 4,1261 & 60175 & & \\
\hline
\end{tabular}




\begin{tabular}{|c|c|c|c|c|c|c|}
\hline \multirow{2}{*}{$\begin{array}{l}\text { İş Kurmak ve İște Başarlı } \\
\text { Olabilmek İçin Önemli Unsurlar }\end{array}$} & Biliyorum & 26 & 4,7115 & ,43091 & \multirow{2}{*}{2,261} & \multirow{2}{*}{0,027} \\
\hline & Bilmiyorum & 35 & 4,3873 & ,62593 & & \\
\hline \multirow{2}{*}{$\begin{array}{l}\text { Girișimci Olmadaki } \\
\text { Faktörlerin Önemi }\end{array}$} & Biliyorum & 26 & 3,7385 & ,54851 & \multirow{2}{*}{$-1,813$} & \multirow{2}{*}{0,075} \\
\hline & Bilmiyorum & 35 & 3,9683 & ,43361 & & \\
\hline \multirow{2}{*}{$\begin{array}{l}\text { En Uygun Yatırım } \\
\text { Alanlarının Önemi }\end{array}$} & Biliyorum & 26 & 2,9657 & 1,07684 & \multirow{2}{*}{0,278} & \multirow{2}{*}{0,782} \\
\hline & Bilmiyorum & 35 & 2,8940 & ,91794 & & \\
\hline
\end{tabular}

$\mathbf{H}_{\mathbf{0}}$ : Girişimcilik faktörlerinin önem düzeyi kadın girişimcilerin yabancı dil bilme durumuna göre anlamlı farklılık göstermez.

$\mathbf{H}_{5}$ : Girişimcilik faktörlerinin önem düzeyi kadın girişimcilerin yabancı dil bilme durumuna göre anlamlı farklılık gösterir.

İşletmede yaşanan sıkıntıların öneminin algısı İngilizce bilen kadın girişimcilerde $(4,0096)$ yabancı dil bilmeyen kadın girişimcilerden $(3,6933)$ daha yüksek düzeydedir. Anlamlılık değerinin $p=0,016<0,05$ olmasından dolayı işletmede yaşanan sıkıntıların önemi için $\mathrm{H}_{0}$ hipotezi reddedilir. Yani, işletmelerde yaşanan sıkıntıların öneminin algısı kadın girişimcilerin İngilizce bilme durumuna göre anlamlı farklılık gösterir.

İş kurmak ve işte başarılı olabilmenin önem algısı İngilizce bilen kadın girişimcilerde $(4,7115)$ İngilizce bilmeyen kadın girişimcilerden $(4,3873)$ daha yüksek düzeydedir. Anlamlılık değerinin $\mathrm{p}=0,027<0,05$ olmasından dolayı bu boyut için $\mathrm{H}_{0}$ hipotezi reddedilir. Yani, iş kurmak ve işte başarılı olmanın önem algısı kadın girişimcilerin İngilizce bilme durumuna göre anlamlı farklılık gösterir.

Diğer boyutlar için anlamlılık değerlerinin $\mathrm{p}>0,05$ olmasından dolayı diğer boyutlarda $\mathrm{H}_{0}$ hipotezi kabul edilir. Yani önem düzeyleri kadın girişimcilerin İngilizce bilme durumuna göre anlamlı farklılık göstermez.

Tablo 10. Girişimcilik Faktörlerinin Önem Düzeyinin İşletmenin Hizmet Süresine Göre Farklılığını İnceleyen F Testi

\begin{tabular}{|c|c|c|c|c|c|c|}
\hline & $\begin{array}{l}\text { Hizmet } \\
\text { Süresi }\end{array}$ & $\begin{array}{l}\text { Kişi } \\
\text { Sayıs1 }\end{array}$ & Ortalama & $\begin{array}{l}\text { Std. } \\
\text { Sapma }\end{array}$ & $\mathrm{F}$ & $\begin{array}{l}\text { Anlamlilik } \\
\text { (P) }\end{array}$ \\
\hline \multirow{5}{*}{$\begin{array}{l}\text { İş Kurarken Karşılaşılan } \\
\text { Sıkıntıların Önemi }\end{array}$} & 1-5 y1l arası & 25 & 4,2423 &, 36235 & \multirow{5}{*}{0,314} & \multirow{5}{*}{0,815} \\
\hline & 6-10 yll aras1 & 19 & 4,1283 & ,38309 & & \\
\hline & $11-15$ yll aras & 5 & 4,2000 & ,56187 & & \\
\hline & 20 yıldan fazla & 12 & 4,2624 &, 53044 & & \\
\hline & Toplam & 61 & 4,2088 & ,41758 & & \\
\hline \multirow{5}{*}{$\begin{array}{l}\text { İșletmede Yaşanan } \\
\text { Sikıntıların Önemi }\end{array}$} & 1-5 y1l aras1 & 25 & 3,8315 & ,46863 & \multirow{5}{*}{1,805} & \multirow{5}{*}{0,157} \\
\hline & 6-10 yll aras1 & 19 & 3,7941 & ,33929 & & \\
\hline & $11-15$ yll arası & 5 & 3,8500 & ,54054 & & \\
\hline & 20 yıldan fazla & 12 & 4,1726 &, 59593 & & \\
\hline & Toplam & 61 & 3,8938 & ,48087 & & \\
\hline \multirow{5}{*}{$\begin{array}{l}\text { Kadın Girişimcilerin Çalışma } \\
\text { Hayatına } \\
\text { Katılmama Sebeplerinin Önemi }\end{array}$} & 1-5 y1l arasi & 25 & 3,7391 &, 55270 & \multirow{5}{*}{0,153} & \multirow{5}{*}{0,928} \\
\hline & 6-10 yll aras1 & 19 & 3,8235 &, 52375 & & \\
\hline & $11-15$ yll aras 1 & 5 & 3,8857 & ,64206 & & \\
\hline & 20 ylldan fazla & 12 & 3,8433 & ,67637 & & \\
\hline & Toplam & 61 & 3,7991 &, 56607 & & \\
\hline \multirow{5}{*}{$\begin{array}{l}\text { İşletmenin Geleceğe Yönelik } \\
\text { Planlarının Önemi }\end{array}$} & $1-5 \mathrm{yll}$ aras1 & 25 & 4,2236 & ,48316 & \multirow{5}{*}{1,681} & \multirow{5}{*}{0,182} \\
\hline & 6-10 yll aras1 & 19 & 4,0364 & ,55978 & & \\
\hline & $11-15$ yll aras1 & 5 & 3,8286 &, 55696 & & \\
\hline & 20 yıldan fazla & 12 & 4,3810 & ,61921 & & \\
\hline & Toplam & 61 & 4,1662 & ,55249 & & \\
\hline \multirow{5}{*}{$\begin{array}{l}\text { İş Kurmak ve İște Başarılı } \\
\text { Olabilmek İçin Önemli Unsurlar }\end{array}$} & $1-5 \mathrm{yll}$ aras1 & 25 & 4,6449 & ,41226 & \multirow{5}{*}{0,115} & \multirow{5}{*}{0,951} \\
\hline & 6-10 yll aras1 & 19 & 4,5490 &, 50265 & & \\
\hline & $11-15$ yll arası & 5 & 4,6000 & ,48016 & & \\
\hline & 20 yıldan fazla & 12 & 4,5833 &, 72300 & & \\
\hline & Toplam & 61 & 4,5994 & ,50969 & & \\
\hline
\end{tabular}




\begin{tabular}{|c|c|c|c|c|c|c|}
\hline \multirow{5}{*}{$\begin{array}{l}\text { Girișimci Olmadaki } \\
\text { Faktörlerin Önemi }\end{array}$} & $1-5$ yll aras 1 & 25 & 3,8391 & ,46782 & \multirow{5}{*}{0,617} & \multirow{5}{*}{0,607} \\
\hline & 6-10 yll aras1 & 19 & 3,8882 &, 48590 & & \\
\hline & $11-15$ yil arası & 5 & 4,1800 & 20494 & & \\
\hline & 20 yıldan fazla & 12 & 3,9250 & ,68639 & & \\
\hline & Toplam & 61 & 3,9018 &, 50762 & & \\
\hline \multirow{5}{*}{$\begin{array}{l}\text { En Uygun Yatırım } \\
\text { Alanlarının Önemi }\end{array}$} & $1-5$ yll arasi & 25 & 2,8591 & ,90502 & \multirow{5}{*}{4,309} & \multirow{5}{*}{0,009} \\
\hline & 6-10 yll arasi & 19 & 2,5319 & 1,01415 & & \\
\hline & $11-15$ yll aras1 & 5 & 2,8875 & 1,44320 & & \\
\hline & 20 yıldan fazla & 12 & 3,7855 & 64391 & & \\
\hline & Toplam & 61 & 2,9590 & 1,02576 & & \\
\hline
\end{tabular}

$\mathbf{H}_{\mathbf{0}}$ : Girişimcilik faktörlerinin önem düzeyi kadın girişimcilerin işletmelerine ait hizmet süresine göre anlamlı farklılık göstermez.

$\mathbf{H}_{6}$ : Girişimcilik faktörlerinin önem düzeyi kadın girişimcilerin işletmelerine ait hizmet süresine göre anlamlı farklılı gösterir.

En uygun yatırım alanlarının önemi ile ilgili algı düzeyi işletmesi 20 yıldan uzun süredir hizmet veren kadın girişimcilerde $(3,7855)$ diğer kadın girişimcilere göre daha yüksek düzeydedir. Anlamlılık değerinin $\mathrm{p}=0,009<0,05$ olmasından dolayı yatırım alanlarının önemi için $\mathrm{H}_{0}$ hipotezi reddedilir. Yani, en uygun yatırım alanlarının önem algısı kadın girişimcilerin işletmelerine ait hizmet süresine göre anlamlı farklılık gösterir.

Diğer faktörler için anlamlılık değerlerinin $\mathrm{p}>0,05$ olmasından dolayı diğer faktörler için $\mathrm{H}_{0}$ hipotezi kabul edilir. Yani, diğer faktörlerin önem düzeyi kadın girişimcilerin işletmelerine ait hizmet süresine göre anlamlı farkl111k göstermez.

Tablo 11. Girişimcilik Faktörlerinin Önem Düzeyinin İş Hayatına Giriş Biçimine Göre Farklılığını İnceleyen F Testi

\begin{tabular}{|c|c|c|c|c|c|c|}
\hline & $\begin{array}{l}\text { İş Hayatına } \\
\text { Başlangıç Biçimi }\end{array}$ & $\begin{array}{l}\text { Kişi } \\
\text { Sayls1 }\end{array}$ & Ortalama & $\begin{array}{l}\text { Std. } \\
\text { Sapma }\end{array}$ & $\mathrm{F}$ & $\begin{array}{l}\text { Anlamlilik } \\
(\mathrm{P})\end{array}$ \\
\hline \multirow{4}{*}{$\begin{array}{l}\text { İş Kurarken Karşılaşılan } \\
\text { Sıkıntıların Önemi }\end{array}$} & Girişimci olarak başladım & 24 & 4,3043 & ,39119 & \multirow{4}{*}{2,496} & \multirow{4}{*}{0,092} \\
\hline & $\begin{array}{l}\text { Özel sektörde başka alanda } \\
\text { çalıştım }\end{array}$ & 16 & 3,9818 & ,49392 & & \\
\hline & Aynı işi ücretli yaptım & 19 & 4,1603 &, 47445 & & \\
\hline & Toplam & 59 & 4,1705 &, 45924 & & \\
\hline \multirow{4}{*}{$\begin{array}{l}\text { İşletmede Yaşanan } \\
\text { Sıkıntıların Önemi }\end{array}$} & Girişimci olarak başladım & 24 & 3,9926 & ,42415 & \multirow{4}{*}{2,489} & \multirow{4}{*}{0,092} \\
\hline & $\begin{array}{l}\text { Özel sektörde başka alanda } \\
\text { çalışım }\end{array}$ & 16 & 3,6563 & ,48197 & & \\
\hline & Aynı işi ücretli yaptım & 19 & 3,7500 & ,59073 & & \\
\hline & Toplam & 59 & 3,8232 & ,51091 & & \\
\hline \multirow{4}{*}{$\begin{array}{l}\text { Kadın Girişimcilerin } \\
\text { Çalışma Hayatına } \\
\text { Katılmama Sebeplerinin } \\
\text { Önemi }\end{array}$} & Girişimci olarak başladım & 24 & 3,7798 &, 50196 & \multirow{4}{*}{, 546} & \multirow{4}{*}{0,582} \\
\hline & $\begin{array}{l}\text { Özel sektörde başka alanda } \\
\text { çalıştım }\end{array}$ & 16 & 3,6071 &, 57735 & & \\
\hline & Aynı işi ücretli yaptım & 19 & 3,7895 &, 66559 & & \\
\hline & \begin{tabular}{|l|} 
Toplam \\
\end{tabular} & 59 & 3,7361 &, 57438 & & \\
\hline \multirow{4}{*}{$\begin{array}{l}\text { İşletmenin } \quad \text { Geleceğe } \\
\text { Yönelik } \\
\text { Planlarının Önemi }\end{array}$} & Girişimci olarak başladım & 24 & 4,2798 & ,46811 & \multirow{4}{*}{1,672} & \multirow{4}{*}{0,197} \\
\hline & $\begin{array}{l}\text { Özel sektörde başka alanda } \\
\text { çalışım }\end{array}$ & 16 & 3,9583 & 66641 & & \\
\hline & Aynı işi ücretli yaptım & 19 & 4,1203 & ,53296 & & \\
\hline & Toplam & 59 & 4,1412 &, 55427 & & \\
\hline \multirow{4}{*}{$\begin{array}{l}\text { İş Kurmak ve İşte Başarılı } \\
\text { Olabilmek İçin Önemli } \\
\text { Unsurlar }\end{array}$} & Girişimci olarak başladım & 24 & 4,5903 &, 53834 & \multirow{4}{*}{,778 } & \multirow{4}{*}{0,464} \\
\hline & $\begin{array}{l}\text { Özel sektörde başka alanda } \\
\text { çalıştım }\end{array}$ & 16 & 4,3750 &, 74660 & & \\
\hline & Aynı işi ücretli yaptım & 19 & 4,5789 & ,44572 & & \\
\hline & \begin{tabular}{|l|} 
Toplam \\
\end{tabular} & 59 & 4,5282 &, 57415 & & \\
\hline \multirow{4}{*}{$\begin{array}{l}\text { Girișimci Olmadaki } \\
\text { Faktörlerin Önemi }\end{array}$} & Girişimci olarak başladım & 24 & 3,9000 & ,45588 & \multirow{4}{*}{,733 } & \multirow{4}{*}{0,485} \\
\hline & $\begin{array}{l}\text { Özel sektörde başka alanda } \\
\text { çalıştım }\end{array}$ & 16 & 3,7701 & 60074 & & \\
\hline & Aynı işi ücretli yaptım & 19 & 3,9684 &, 41640 & & \\
\hline & Toplam & 59 & 3,8868 &, 48535 & & \\
\hline
\end{tabular}




\begin{tabular}{|c|c|c|c|c|c|c|}
\hline \multirow{4}{*}{$\begin{array}{l}\text { En Uygun Yatırım } \\
\text { Alanlarının Önemi }\end{array}$} & Girişimci olarak başladım & 24 & 2,9532 & 1,03617 & \multirow{4}{*}{,192 } & \multirow{4}{*}{0,826} \\
\hline & $\begin{array}{l}\text { Özel sektörde başka alanda } \\
\text { çalıştım }\end{array}$ & 16 & 2,9784 & ,78429 & & \\
\hline & Aynı işi ücretli yaptım & 19 & 2,7928 & 1,09747 & & \\
\hline & Toplam & 59 & 2,9084 & ,98244 & & \\
\hline
\end{tabular}

$\mathbf{H}_{\mathbf{0}}$ : Girişimcilik faktörlerinin önem düzeyi kadın girişimcilerin iş hayatına giriş biçimine göre anlamlı farkl111k göstermez.

$\mathbf{H}_{7}$ : Girişimcilik faktörlerinin önem düzeyi kadın girişimcilerin iş hayatına giriş biçimine göre anlamlı farkl11ık gösterir.

Girişimcilik faktörlerinin kadın girişimcilerin iş hayatına giriş biçimine göre farklılık gösterip göstermediğini test etmek amacıyla yapılan $F$ testi sonucuna göre anlamlılık değerlerinin $p>0,05$ olmasından dolayı tüm faktörler için $\mathrm{H}_{0}$ hipotezi kabul edilir. Yani, girişimcilik faktörlerinin önem düzeyi kadın girişimcilerin iş hayatına giriş biçimine göre anlamlı farklılık göstermez.

\section{SONUÇ VE DEĞERLENDİRME}

Girişimci olarak çalışma hayatına dâhil olan kadın, cinsiyetinden ötürü iş ve sosyal hayatın erkek egemen düzene sahip şartları içerisinde yaşamını sürdürmeye çalışmaktadır. Ancak son yıllarda kadınların iş hayatlarında karşı cinse oranla başarı oranlarında artış söz konusudur. Bunun sebebi olarak erkeklerle aralarında bilgi ve deneyim farkının gün geçtikçe azalması ve yapılarının bir getirisi olarak olaylara daha duyarlı ve sakin bakabilmeleri, insan ilişkilerinde daha etkin olmaları gösterilebilir. $\mathrm{Bu}$ kapsamda sosyal ve ekonomik öneme sahip olduğu öngörülen girişimci kadınların kaynak optimizasyonu, beşeri ilişkilerde etkin olma ve çalışma hayatında edinilen tecrübelerin verimli aktarılması gibi özelliklere sahip olması onları girişimcilik bağlamında bir üst seviyeye taşıyacaktır.

Kadın girişimcilik oranlarında seviye yükselmekle birlikte istenilen orana henüz ulaşılamamıştır. Kadınların iş hayatında yer almasının önünün açılması adına KOSGEB'in sağlamış olduğu "Girişimcilik Desteği" nde cinsiyetten ötürü pozitif ayrımcılık yapılmaktadır. Bununla beraber kadın girişimcilerin gelişimine destek veren sivil toplum kuruluşlarının da genel anlamda birtakım faaliyetleri bulunmaktadır. Girişimciliğin geliştirilmesi adına Onuncu Kalkınma Planı (2014-2018)'nda girişimcilik olgusunun erken çağlarda aşılanması ile bilinçlenme sağlanması, eğitim sistemi içerisine de girişimcilik kültürünün dâhil edilmesi, sadece ticaret, sanayi ve hizmet sektörlerinde değil, tarım ve üretim sektörlerinde de girişimciliğin yaygınlaştırılması esas alınmıştır.

$\mathrm{Bu}$ bağlamda Çorum ili bakımından imalat sektöründeki girişimciler üzerine bir değerlendirme yapıldığında TÜiK verilerinden elde edilen bilgiler doğrultusunda Çorum Çalışma ve İş Kurumu İl Müdürlüğü tarafından 2018 yılında yapılan bir piyasa analiz çalışması bize yol gösterici olacaktır. Bu araştırma mevcut istihdam seviyesini ortaya çıkarmak, işgücü piyasasındaki dalgalanmaları öngörerek ileri safhalarda bu duruma yönelik stratejiler geliştirmek ve açık iş oranının yüksek olduğu iş sektörüne yönlenmek açısından önem kazanmaktadır.

Bu çalışmada hizmet üretiminde kadın girişimciliğinin yeri, Çorum ili baz alınarak belirlenmeye ve bu hususta değerlendirme yapılmaya çalışılmıştır. Bu amaçla kütle basit tesadüfi örnekleme yöntemi kullanılarak 61 kadın girişimci seçilmiş ve çalışma nicel araştırma yöntemlerinden biri olan anket yöntemi kullanılarak desteklenmiştir. Anket sonucunda elde edilen veriler SPSS 21.0 veri analiz programı dâhilinde kullanılarak gerekli test ve analiz metodları uygulanmıştır.

Elde edilen sonuçlar doğrultusunda anket çalışması yapılan kadın girişimcilerin sektörlerine bakıldığında kuaför ve kişisel bakım, büro hizmetleri ve restoran gibi hizmet sektörleri üzerinde yoğunlaştığı söylenebilir. Bunun yanı sıra üretken ve verimli olma isteği, bağımsız olma ve kendi işyerinde çalışma arzusu, ekonomik özgürlüğe ulaşabilme gibi sebepler kadınların girişimci olmalarında etkin faktörler olarak nitelendirilebilir.

Kadınların yatırım kararlarında sabırlı davranmaları, katlanılabilir risk üstlenme yönleri ile girişimcilikte daha az başarısızlık göstermişlerdir. Buna karşılık kadınların finansal açıdan eksiklikler veya teknik bilgi yetersizlikleri kadın girişimcilerin girişimcilik boyutunda olumsuz yönlerini oluşturmaktadır. İstihdam 
seviyesi sektörel açıdan incelendiğinde, bu dağılımın illerin temel ekonomik faaliyetlerinin bir göstergesi sayılabileceği öngörülmektedir. Kadın girişimciler genellikle hizmet sektörüne yönelmektedir. Bunun sebebi başlangıçta düşük sermayeye ihtiyaç duyulması, işe giriş kısıtlamalarının az olması gibi gerekçeler gösterilebilir. Hizmet sektörünü, sanayi ve tarım sektörü takip etmektedir. Bu genelleme Çorum ili için de geçerlidir.

Özetle ifade etmek gerekirse, hem ülkemiz hem de Çorum ili açısından kadın girişimcilerin istihdama katkısını sağlamak önemlidir. Üretim sektörünün önemli olması sebebiyle kadın girişimcileri bu sektöre yönlendirmek, KOSGEB gibi çeşitli kurumlar aracıllğı ile finansal yönden desteklenmek ve kadın girişimcilere yönelik pozitif ayrımcılık çerçevesinde stratejiler izlemek kadın girişimcilerin istihdama katkıda bulunmasını sağlayabilmektedir. Kadın girişimciliğine destekte bulunan ve özendiren stratejilerin kadın girişimcilerin örgütlenme seviyelerine yönelik olması daha uygundur. $\mathrm{Bu}$ sebeple kooperatifçiliğin yaygınlaştırılması, ekonomik üretime kadınların da katılmalarını teşvik eder ve kırsal kalkınmada önemli bir rol üstlenir. Kadınlar arasındaki dayanışma ve beraber hareket etme yetisinin geliştirilmesi, kadınların güçlenmesi ve nüfuz etme becerilerinin artırılması, cinsiyetten kaynaklanan sorunların önüne geçilmesi, sürdürülebilir kalkınma ve refah seviyesinin yükseltilmesi kooperatifçilik ile mümkün olmaktadır. Bu yönüyle kooperatifçilik faaliyeti de kadınların üretim sektörüne katılımında rol üstlenmektedir. Dolayısıyla genel olarak kadınlara yönelik teşvik politikaları, çeşitli kurum ve kuruluşlarca kadın girişimciliğinin desteklenmesi, kooperatifçiliğin yaygınlaştırılması gibi etmenler ile Çorum ilindeki kadın girişimcileri üretim alanına yönlendirmek, üretimdeki yoğun işgücü açığının bir nevi azalmasina sebebiyet verecektir.

Bilgilendirme / Acknowledgement: Bu çalışma, Şenöz, A, (2018), "Hizmet Sektöründe Kadın Girişimciler: Çorum Araştırması", Hitit Üniversitesi SBE, Yüksek Lisans Tezi, çalışmasından üretilmiştir.

\section{KAYNAKÇA}

Acar, N. (1998). Üretim planlaması yöntem ve uygulamaları. Ankara: Milli Prodüktivite Merkezi Yayınları.

Alkan, M. (2014). Girişimcilerin girişimcilik, inovasyon yapma inovatif düşünce ve inovatif girişimcilik düzeylerinin incelenmesi, 2, 1-26.

Anderson, C. ve Schneier, C. (1978). Locus of control, leader behavior and leader performance among management students. The Academy of Management Journal, 4(21), 36-37, 690-698.

Arıkan, S. (2004). Girişimcilik temel kavramlar ve bazı güncel konular. Ankara: Siyasal Kitapevi.

Atik, S. (2002). Kültürün girişimciliğe etkileri. Kara Harp Okulu Bilim Dergisi, 3, 38-48.

Aytaç, Ö. ve İlhan, S. (2007). Girişimcilik ve girişimci kültür: Sosyolojik bir perspektif. Selçuk Üniversitesi Sosyal Bilimler Enstitüsü Dergisi, 18, 102-117.

Barbato, R., Demartino, R. ve Jacques, P. (2009, Spring). The entrepreneurial motivations of nonemployer entrepreneurs. New England Journal Of Entrepreneurship, 1(12), 33-44.

Başar, M. (2013). Girişimcilik içinde ünite 1: Girişimcilik ve girişimcilik süreçleri. Eskişehir: Anadolu Üniversitesi Yayını.

Bedük, A. (2005). Türkiye'de çalışan kadın ve kadın girişimciliği. Elektronik Sosyal Bilimler Dergisi, 3(12), 106-117.

Bozkurt, Ö., Kalkan, A., Koyuncu, O. ve Alparslan, A. M. (2012, Ocak). Türkiye'de girişimciliğin gelişimi: Girişimciler üzerinde nitel bir araştırma. Süleyman Demirel Üniversitesi Sosyal Bilimler Enstitüsü Dergisi, 15, 229-247. 
Büyükkeklik, M. (2007). Üretim planlama problemlerinde doğrusal programlama modellerinin kullanımı: Bir üretim işletmesinde uygulama. Yüksek lisans tezi, Niğde Üniversitesi, Niğde.

Casson, M., Yeung, B., Basu, A. ve Wadeson, N. (2006). The Oxford handbook of entrepreneurship. Great Britain: Oxford University Press.

Cici, E. N. (2013). Kadınların girişimcilik yolunda karşslaş̧tıkları sorunların öz girişimcilik yetenekleri üzerindeki etkisi: Konya ilinde bir araştırma. Yüksek lisans tezi, Selçuk Üniversitesi, Konya.

Çelik, A. ve Akgemci, T. (1998). Girişimcilik kültürü ve KOBİler. Ankara: Nobel Yayınevi.

Çetin, C. (1996). Yeniden yapılandırma-girişimcilik ve küçük ve orta boy işletmeler ve bunların özendirilmesi. İstanbul: Der Yayınları.

Çetin, M. (2013). Erzincan meslek yüksekokulu öğrencilerinin girişimcilik algısı ve girişimcilik profili. Uluslararası Girişimcilik ve Kariyer Sempozyumu Bildiriler Kitabı, Muğla, 570-590.

Demir, N. (2015). Türkiye'de girişimcilik ve kadın. Kalkınmada Anahtar Verimlilik, 315.

Dhillon, P. (1993). Women entrepreneurs: Problems and prospects. New Delhi: Blaze.

Dilsiz, İ. ve Kölük, N. (2005). Girişimcilik. Ankara: Detay Yayıncılık.

Dinçer, Ö. (1999). İşletme yönetimine giriş. İstanbul: Beta Yayınevi.

Ecevit, Y. (1993). Kadın girişimciliğinin yaygınlaşmasına yönelik bir model önerisi. Kadın girişimciliğin yaygınlaşmasına yönelik bir model önerisi, Kadın Girişimciliğe Özendirme ve Destekleme Paneli Bildiriler ve Tartışmalar, Devlet Bakanlığı Kadın ve Sosyal Hizmetler Müsteşarlığı Kadının Statüsü ve Sorunları Genel Müdürlüğü, Eğitim Semineri, 74, 30-35.

Erdem, F. (2001). Girişimcilerde risk alma eğilimi ve belirsizliğe tolerans ilişkisine kültürel yaklaşım. Akdeniz İ.I.B.F. Dergisi, 2, 43-61.

Palaz Erdemir, H. (2012). Wollen textiles: An international trade good in the lycus valley in antiquity. Colossae in Space and Time Linking to an Ancient City. (Cadwallader, A. H. \& Trainor, M., Edt.). Leiden: Vandenhoeck and Ruprecht, 104-129.

Erdemir, H. ve Palaz Erdemir, H. (2016). İnovasyonun ulusal ve uluslararast gelişim ve rekabete etkisi. Bişkek: ICE 2016-7th International Congress on Entrepreneurship Bildiri Kitabı. 59-78.

Erktürk, E. (2015). Girişim ilham kaynakları. Startup Doğan Burda Dergi Yayıncılık.

Gökakın, Z. (2000). Doksanlı yılların yeni kahramanları: Türkiye'de girişimci kadın profili. Nevşehir: 8. Yönetim ve Organizasyon Kongresi Bildiriler Kitabı.

Gönüllü, M. ve İçli, G. (2001). Çalışma yaşamında kadınlar: Aile ve ev ilişkileri. Cumhuriyet Üniversitesi Sosyal Bilimler Dergisi, 25(1), 81-100.

Gusseinova, D. (2015). Sosyal girişimcilik olgusu ve bir örnek olay incelemesi. Yüksek lisans tezi, Dokuz Eylül Üniversitesi, İzmir.

Güney, S. (2006). Kadın girişimciliğine genel bakış. Girişimcilik ve Kalkınma Dergisi, 1(1), 25-43. Gürdoğan, N. (2008). Girişsimcilik ve girişim kültürü. İstanbul: İgiad Yayınları. 
Gürol, M. A. (2000). Türkiye'de kadın girişimci ve küçük işletmesi: Fırsatlar, sorunlar, beklentiler ve öneriler. Ankara: Atılım Üniversitesi Yayınları.

Güzel, M. (2010). Ekonomi ve üretim ilişkisi. Araşstırma-Ekonomi ve Üretim İlişkisi.

Hisrich, D. R. (2002). Entrepreneurship. USA: McGraw Hill Higher Education.

Hisrich, R., \& Peters, M. (1998). Entrepreneurship. New York: Irwin Mc Graw Hill.

Hughes, K. (2003). Pushed or pulled? Women's entry into self-employment and small business ownership. Gender, Work and Organization, 10(4), 437-438.

İlter, B. (2010). Girişimcilik sürecinde kadın girişimcilerin karşıllaştıkları sorunların analizi: KAGIDER örneği. Ankara: Adalet Yayınevi.

İraz, R. (2005). Yaratıcılık ve yenilik bağlamında girişimcilik ve KOBİler. Konya: Çizgi Kitapevi.

İrmiş, A., \& Barutçu, E. (2012). Öğrencilerin kendilerini girişimci bir kişiliğe sahip görmelerini ve iş kurma niyetlerini etkileyen faktörler: Bir alan araştırması. Atatürk Üniversitesi İktisadi ve İdari Bilimler Dergisi, 26(2), 1-2.

İş ve Meslek Sahibi Kadınlar Derneği. (2010). Konya saha çalışması raporu.

Kağnıcıoğlu, H., Aydın, S., Hasgül, S. ve Anagün, S. (2012). Üretim yönetimi. Eskişehir: Anadolu Üniversitesi Yayınları.

Karalar, R., Özalp, İ., Maviş, F., Geylan, R., Tenekecioğlu, B., Şahin, M. ve Aydın, N. (2006). Genel işletme. Eskişehir: Anadolu Üniversitesi Yayınları.

Keskin, S. (2014). Türkiye'de kadın girişimcilerin durumu. Girişimcilik ve Kalkınma Dergisi, 9(1), 84.

Kobu, B. (2008). Üretim yönetimi. İstanbul: Beta Basım Yayın

Kurt, S. ve Savrul, M. (2016). Girişimcilik faaliyetlerinin ekonomik büyüme üzerindeki etkisi: Nascent örneği. Girişimcilik ve Kalkınma Dergisi, 6(2), 341-355.

Kutanis, R. ve Alpaslan, S. (2006). Girişimci ve yönetici kadınların profili farklı mıdır? Afyon Kocatepe Üniversitesi IBF Dergisi, 8(2), 139-153.

Küçük, O. (2005). Girişimcilik ve küçük işletme yönetimi. Ankara: Seçkin Yayınc1lık.

Küçükaltan, D. (2009). Genel bir yaklaşımla girişimcilik. Girişimcilik ve Kalkınma Dergisi, 4(1), 2128.

Landström, H. (2005). Pioneers in entrepreneurship and small business research. Springer Science.

Mungan, S. (2013). Kadın girişimcilik değerleri ile kadın girişimcilik algısı arasındaki ilişkide girişimcilik eğitimlerinin rolü. Yüksek lisans tezi, Marmara Üniversitesi, İstanbul.

Narin, M., Maşrap, A. ve Gürol, M. A. (2006). Global kadın girişimciliğinin maksimizasyonunu hedefleme: Uluslararası arenada örgütlenme ve ağ oluşturma. Gazi Üniversitesi İktisadi ve İdari Bilimler Dergisi, 8(1), 69.

Nayır, D. Z. (2008). İşi ve ailesi arasındaki kadın: Tekstil ve bilgi işlem girişimcilerinin rol çatışmasına getirdikleri çözüm stratejileri. Ege Akademik Bakış, 8(2), 631-650.

Odabaşı, Y. (2005). Girişimcilik. Eskişehir: T.C. Anadolu Üniversitesi Yayını. 
Özdevecioğlu, M. ve Cingöz, A. (2009). Sosyal girişimcilik ve sosyal girişimciler: Teorik çerçeve. Erciyes Üniversitesi İktisadi ve İdari Bilimler Fakültesi Dergisi, 1(32), 81-95.

Özkul, G. (2007). Kapitalist sistemin sürükleyici aktörleri: Ekonomik teoride girişimciler. Süleyman Demirel Üniversitesi İktisadi ve İdari Bilimler Fakültesi Dergisi, 3(12), 343-366.

Özkul, G. ve Dulupçu, M. (2007). Kişisel gelişimin girişimci tipleri üzerine etkisi: Antalya-Isparta illerinde bir inceleme. Çanakkale Onsekiz Mart Üniversitesi Girişimcilik ve Kalkınma Dergisi, $2(2), 89$.

Öztürk, M. D. (2016). Türkiye'de kadın girişimcilik: Kadınları girişimciliğe yönelten faktörler, karşılaş̧ıkları sorunlar ve çözüm önerileri. Yüksek lisans tezi, İstanbul Ticaret Üniversitesi, İstanbul.

Özyılmaz, A. M. (2016). Türkiye'de kadın girişsimciliği ve girişimci kadınların karşılaştıkları sorunlar üzerine bir araştırma. Yüksek lisans tezi, Nevşehir Hacı Bektaş Veli Üniversitesi, Nevşehir.

Palaz Erdemir, H. (2018). Eskiçağ Anadolu ekonomik hayatında kadın emeği ve dokuma. Anadolu'nun Eski Çağlarında İktisadi ve Zirai Hayat. (Gökçek, L. G., Yıldırım, E., Pekşen O., Edt.). İstanbul: Değişim Yayınları.

Rajavel, S. (2016). Challenges of women entrepreneurs. Primax International Journal of Commerce and Management Research, 12-14.

Rauch, A. ve Frese, M. (2000). Psychological approaches to entrepreneurial success: A general model and an overview of findings. International Review of Industrial and Organizational Psychology, 101-142.

Russell, S. ve Taylor, W. (1995). Production and operations management focusing on quality and competitiveness. New Jersey: Prentice-Hall.

Saray, G. (1993). Türkiye'de kadın girişimciliği, kadını girişimciliğe özendirme ve destekleme paneli. Devlet Bakanlı̆̆ı Kadın ve Sosyal Hizmetler Müsteşarlı̆̆ı Kadının Statüsü ve Sorunları Genel Müdürlüğ̈̈ Ĕ̈itim Serisi, Ankara, 117-125.

Sinanoğlu Koç, E. (2005). Kadın girişimciler kavramı ve serbest meslek mensubu kadın girişimcilere ilişskin konya ilinde uygulamalı bir araştırma. Selçuk Üniversitesi, Konya.

Sipahi, E. (1997). Türkiye'de girişimcilik ve kadın girişimciler üzerine bir araştırma. İstanbul Üniversitesi, İstanbul.

Smith, N. ve Miner, J. (1983). Type of entrepreneur, type of firm, and managerial motivation: Implications for organisational life cycle theory. Strategic Management Journal, 4, 225-240.

Soysal, A. (2010). Türkiye'de kadın girişimciler: Engeller ve firsatlar bağlamında bir değerlendirme. Ankara Üniversitesi Sbf Dergisi, 65(1), 84-114.

Soysal,A.(2010). Kadın girişimcilerin özellikleri, karşılaştıkları sorunlar ve iş kuracak kadınlara öneriler: Kahramanmaraş ilinde bir araştırma. Eskişehir Osmangazi Üniversitesi İ̈BF Dergisi, 5(1), 71-95. 
Takay, B. A., Tüzün, İ. K., Kıral, S., Çiftçi, S. ve Batum, U. (2014). Ankara'da kadın girişimciliği örnekler ve yol haritası. Ekim 2014 Araştırmalar Serisi-2. Ankara: Ankara Kalkınma Ajansı.

Tekin, M. (2005). Hayallerin gerçeğe dönüşümü: Girişimcilik. Konya: Günay Ofset.

Tekin, M. (2012). Üretim yönetimi. Konya: Günay Ofset.

Tosunoğlu, T. (2003). Girişimcilik ve Türkiye'nin ekonomik gelişme sürecinde girişsimciliğin yeri. Doktora tezi, Eskişehir Anadolu Üniversitesi, Eskişehir.

TÜSİAD. (2002). Türkiye'de girişimcilik. TÜSİAD Yayınları.

Üreten, S. (2002). Üretim / işlemler yönetimi stratejik kararlar ve karar modelleri. Ankara: Gazi Kitapevi.

Üreten, S. (1998). Üretim / işlemler yönetimi planlama ve denetim kararlarl, karar modelleri ve iyileştirme yaklaşımları. Ankara: Gazi Üniversitesi Yayınları.

Weiler, S. ve Bernasek, A. (2001). Dodging the glass ceiling? Networks and the new wave of women entrepreneurs. The Social Science Journal, 38, 85-103.

Yamak, O. (1999). Üretim yönetimi. İstanbul: Alfa Basım Yayın.

Yaşar, F. (2017). Düzce ilinde kadın girişimcilik profilinin belirlenmesi. Yüksek lisans tezi, Düzce Üniversitesi, Düzce.

Yetim, N. (2002). Sosyal sermaye olarak kadın girişimciler: Mersin örneği. Ege Akademik Bakış; Ekonomi, İşletme, Uluslararası İlişkiler ve Siyaset Bilimi Dergisi, 2(2), 79-92.

Yörük, D. ve Ağca, V. (2006). Bağımsız girişimcilik ve iç girişimcilik arasındaki farklar: Kavramsal bir çerçeve. Afyon Kocatepe Üniversitesi İktisadi ve İdari Bilimler Dergisi, 2(8), 155-173. 